\title{
ARCHIWA HETMANÓW KORONNYCH POJĘCIE, CHARAKTER I TYPOLOGIA DOKUMENTACJI
}

\section{ARChIWUM hetMaŃSKIE - POJĘCIE}

D) roces tworzenia się archiwów hetmanów koronnych, tak nietypowy dla innych urzędów ministerialnych Rzeczypospolitej szlacheckiej, nastręcza wielu problemów związanych z określeniem ich istoty. Pojawia się bowiem pytanie, jaką część pozostałości archiwalnej osób sprawujących urzędy hetmańskie można nazwać bez wątpienia archiwum hetmańskim. Czy mówiąc o archiwum hetmańskim, mówi się o archiwum urzędu hetmańskiego, czy też o archiwum osobistym hetmana? Czy możliwe jest w końcu wydzielenie, oczywiście teoretyczne, $\mathrm{z}$ archiwum osobistego archiwum urzędu hetmańskiego?

Archiwa hetmanów wielkich i polnych, zarówno koronnych, jak i litewskieh, nigdy nie funkcjonowały w ramach organizacyjnych choćby zbliżonych do archiwów innych urzędów ministerialnych Rzeczypospolitej Obojga Narodów. Pozostaje więc uznanie archiwów hetmańskich za część archiwów prywatnych, a dokładniej mówiąc - za fragmenty zasobów archiwów rodów i rodzin, z których wywodzili się hetmani. Definiując archiwum hetmańskie, można stosować różne kryteria je opisujące. Najbardziej przekonujące jest kryterium zasobu archiwalnego, pozwalające scharakteryzować to archi- 
wum na kilka sposobów. Po pierwsze, do zasobu archiwum hetmańskiego można zaliczyć tylko archiwalia bezpośrednio związane z piastowaniem godności hetmana, począwszy od aktu (aktów w przypadku osoby sprawującej urząd hetmana polnego i wielkiego) nominacyjnego na urząd, przez archiwalia odzwierciedlające sprawowanie przez hetmanów właściwej władzy wojskowej, administracyjnej, skarbowej, sądowniczej i dyplomatycznej, po korespondencję odnoszącą się wyłącznie do spraw związanych z dzierżeniem buławy. Po drugie, za archiwum hetmańskie można uznać całość archiwaliów, które narastały w archiwum prywatnym osoby piastującej godność hetmańską od chwili uzyskania nominacji. Nierzadko bowiem daje się zauważyć związek pomiędzy sprawowaniem urzędu a innymi kierunkami działalności publicznej i prywatnej hetmanów. Po trzecie, za archiwum hetmańskie uznamy wszystkie archiwalia jak w wariancie drugim, z dołączeniem dokumentacji bezpośrednio odnoszącej się do osoby hetmana, odzwierciedlającej jego karierę publiczną, powstałej jednak przed nominacją na urząd hetmański. Do tej grupy wchodziłyby akta nominacyjne na urzędy i godności centralne, nadworne i ziemskie, nadania królewszczyzn oraz inne archiwalia stanowiące odbicie działalności publicznej z okresu przedhetmańskiego. Po czwarte, archiwum hetmańskie można uznać za spuściznę archiwalną, wówczas zasób tego archiwum będą tworzyć wszystkie archiwalia związane z wszelką działalnością osoby sprawującej urząd hetmański.

Wydaje się, że spośród wyżej wymienionych możliwości zdefiniowania zasobu archiwum hetmańskiego najbardziej zgodny z ogólnie przyjętymi zasadami kwalifikowania akt i określenia ich przynależności, w przypadku dokumentacji urzędu państwowego, jest wersja pierwsza. Oddaje ona najtrafniej regułę związku akt wytworzonych w toku działalności urzędu państwowego z ich twórcą. Trzeba jednak zdać sobie sprawę z bardzo istotnego faktu, a mianowicie, że urzędy hetmańskie były specyficzną instytucją w ustroju Rzeczypospolitej szlacheckiej. Duża niezależność hetmanów, a czasami wręcz ich nieograniczona samowola stały na przeszkodzie zaliczeniu ich do grona urzędników państwowych sensu stricto. Znalazło to również wyraz w pozostałości archiwalnej po hetmanach, gdyż obok dokumentacji z całą pewnością odzwierciedlającej zwyczajowo uznane kompetencje hetmanów, spotyka się dużą grupę archiwaliów, niemających bezpośredniego związku z działalnością urzędu hetmańskiego. Nie ulega jednak wątpliwości, że powstały one i znalazły się w archiwach prywatnych hetmanów tylko dlatego, że sprawowali oni właśnie tę godność. Chodzi tu między innymi o bardzo liczną korespondencję o charakterze prywatnym adresowaną do hetmanów, w której często przewijają się akcenty dotyczące wysokiej pozycji społecznej i politycznej 
jej odbiorców. Ponadto w archiwach hetmańskich zrastają się ze sobą bardzo silnie właściwe akta hetmańskie z aktami powstałymi $\mathrm{w}$ związku z pełnieniem przez hetmanów innych funkcji. Jako przykład można podać chociażby dokumentację, zgromadzoną w archiwum Adama Mikołaja Sieniawskiego, piastującego, podobnie jak większość hetmanów, wraz z hetmaństwem inne godności o charakterze senatorskim, czasem nawet ministerialnym. W archiwum Sieniawskiego znajdują się różnego rodzaju petycje, prośby kierowane przez władze miast, podległych hetmanowi z racji sprawowania przez niego urzędu starosty. W owych suplikach często proszono hetmana, aby wykorzystując swoje uprawnienia, pomógł petentom w załatwieniu problematycznych spraw. Jeszcze bardziej jaskrawy przykład dotyczy dokumentacji, która narosła w archiwum Jana Zamoyskiego. Piastował on jednocześnie godność kanclerza i hetmana wielkiego koronnego. Próba idealnego rozdzielenia archiwaliów w jego archiwum na dwie grupy, odpowiadające sprawowaniu obu urzędów, nastręczyłaby nie lada problemów. W końcu - jak potraktować archiwalia o charakterze politycznym występujące w prawie każdym archiwum prywatnym okresu staropolskiego? Nie ma chyba wątpliwości, że w większości archiwów hetmańskich takiej dokumentacji było bardzo dużo właśnie w związku ze sprawowaniem przez ich twórców urzędu o kluczowym znaczeniu dla funkcjonowania państwa. Może więc druga wersja definicji archiwum hetmańskiego bardziej odpowiadałaby prawdzie o nim, poszerzając granice jego zasobu o dokumentację odzwierciedlającą publiczną działalność hetmanów. Trzecia możliwość określenia archiwum hetmańskiego wyraźnie odbiega pod względem genetycznym od dwóch pierwszych, dopuszcza bowiem możliwość uznania za archiwalia hetmańskie dokumentacji, która powstała w okresie przedhetmańskim. Trzeba jednak pamiętać o tym, że osoba otrzymująca buławę żyła w określonym środowisku, była połączona licznymi formalnymi i nieformalnymi więzami zależności, dlatego też jej późniejszą aktywność nadal warunkowały, przynajmniej częściowo, koneksje z okresu wcześniejszego. Najmniej przekonująca jest ostatnia wersja definicji zasobu archiwum hetmańskiego, zakładająca, że jest on właściwie spuścizną archiwalną pozostałą po hetmanie, obejmującą zasięgiem chronologicznym okres całego jego życia oraz wszystkie sfery działalności.

Problem zdefiniowania archiwum hetmańskiego komplikuje się jeszcze bardziej, gdy weźmie się pod uwagę stan zachowania archiwów hetmańskich. W chwili obecnej najlepiej zachowane są archiwa hetmanów osiemnastowiecznych: Adama Mikołaja Sieniawskiego, Rzewuskich (Stanisława Mateusza, Wacława i Seweryna) oraz Jana Klemensa Branickiego. Można więc $\mathrm{z}$ dużym prawdopodobieństwem określić stan zasobu archiwów hetmańskich 
właśnie dla tego stulecia. Co więcej, archiwum Adama Sieniawskiego, który piastował urząd hetmana w latach 1702-1726, pozwala poznać zasób archiwum hetmańskiego w czasie największego rozkwitu władzy tego urzędu (okres wojny północnej), zahamowanego postanowieniami Sejmu Niemego z 1717 r. Dużo gorzej przedstawia się natomiast stan zachowania archiwów hetmańskich z XVI i XVII w. Zasadniczo z wyjątkiem archiwum Jana Zamoyskiego, sprawującego godność hetmana na przełomie XVI i XVII w., do dnia dzisiejszego nie zachowało się w większym fragmencie ani jedno archiwum hetmańskie z tego okresu. Te, które przetrwały, mają charakter szczątkowy bądź fragmentaryczny. W przeważającej mierze w większej liczbie pozostała z nich tylko korespondencja, choć w przypadku niektórych archiwów hetmańskich brak nawet i jej.

\section{PrywatNy CHARAKTER ARCHIWów HeTMAŃSKICH - PRZYCZYNY}

Akta powstające $\mathrm{w}$ czasie sprawowania urzędu przez poszczególnych hetmanów były traktowane jako ich własność prywatna i jako akta osobiste wchodziły do zasobów ich archiwów. W ten sposób wytworzyła się dosyć paradoksalna sytuacja, kiedy to dokumentacja jednego z najważniejszych urzędów w państwie, urzędu, w którym nierzadko społeczeństwo szlacheckie i osoba panującego widziały zagrożenie dla swoich interesów i bezpieczeństwa państwa, znalazła się poza publicznym obiegiem i kontrolą. Należałoby zastanowić się, dlaczego tak się stało, co zadecydowało o odmienności dziejów archiwów związanych z urzędem hetmańskim od tych, które odzwierciedlały działalność innych centralnych urzędów państwowych.

$\mathrm{Na}$ prywatną proweniencję akt wytworzonych w toku sprawowania władzy hetmańskiej miało wpływ co najmniej kilka czynników. Po pierwsze, stosunkowo późne, w porównaniu $\mathrm{z}$ innymi urzędami centralnymi, ukonstytuowanie się urzędu hetmańskiego w hierarchii urzędów ministerialnych i dygnitarstw koronnych. Po drugie, brak szczegółowego, konkretnego sprecyzowania kompetencji władzy hetmańskiej. Po trzecie, bardzo rozległy zakres uprawnień związanych z hetmaństwem. Po czwarte, brak nadzoru króla, sejmu i senatu nad osobami sprawującymi urząd hetmański. Po piąte wreszcie, duża mobilność hetmanów wynikająca z piastowania urzędu wymagającego częstej zmiany miejsca pobytu.

Hetmaństwo przez długi czas nie było uznawane za stały urząd, lecz traktowane jako doraźnie sprawowana funkcja. Bez wątpienia ciągłe zmiany wśród 
dowódców, powoływanych zwykle tylko na czas trwania wyprawy wojennej, nie wpływały stabilizująco na ukonstytuowanie się urzędu hetmańskiego. Dopiero od początku XVI w. osoby wyznaczane do pełnienia funkcji hetmańskiej zajmowały to stanowisko nieprzerwanie przez okres kilku, ewentualnie kilkunastu lat. Jednak jeszcze Jan Tarnowski, który sprawował władzę hetmańską przez lat ponad trzydzieści, kilkakrotnie zrzekał się buławy hetmańskiej, uznając, że nie zapewnia mu ona ani odpowiedniego statusu wśród innych urzędników i dygnitarzy koronnych, ani nie są z nią związane intratne dochody. Praktycznie dopiero konstytucje sejmowe z końca XVII oraz z XVIII w. formalnie określiły hetmaństwo jako urząd ministerialny, z prawem do zasiadania w senacie, wynikającym tylko i wyłącznie z racji jego sprawowania. Dotychczas hetmani zasiadali w senacie dzięki jednoczesnemu piastowaniu buławy i urzędu senatorskiego (ministerialnego, wojewodzińskiego lub kasztelańskiego). W porównaniu więc z pozostałymi urzędami ministerialnymi, to jest marszałkostwem, kanclerstwem oraz podskarbstwem, które miały o wiele wcześniejszy rodowód, sięgający XII-XIII w., hetmaństwo było opóźnione o prawie trzy stulecia. W XVI w., kiedy nabrało ono cech stałego urzędu, kiedy powoli uznawano potrzebę i konieczność jego funkcjonowania, urzędy marszałka, kanclerza i podskarbiego odgrywały niebagatelną rolę w życiu politycznym i społeczno-gospodarczym całego kraju, tym bardziej jeżeli sprawowały je wybitne jednostki, a tych w dziejach Rzeczypospolitej nie brakowało.

Wokół centralnych urzędów wyrosła liczna grupa urzędników, których praca coraz częściej znajdowała odzwierciedlenie w materiale aktowym. Zasadniczo przy każdym z wyżej wymienionych urzędów powstała kancelaria obsługująca jego bieżącą działalność, a jednocześnie mająca za zadanie przechowywanie dokumentacji wyłączonej z bieżącego obiegu, dokumentacji o charakterze archiwalnym. W ten sposób przy urzędzie podskarbiego wielkiego koronnego utworzono na początku XVI w. kancelarię podskarbińską, której wytworem było co najmniej kilkaset ksiąg i dziesiątki tysięcy luźnych akt, w późniejszym czasie zarchiwizowanych w tak zwanym Archiwum Podskarbińskim Krakowskim oraz Archiwum Podskarbińskim Warszawskim. Częściowo trafiły one również do Archiwum Dóbr Stołowych (Archiwum Kameralne)'1. Także

${ }^{1}$ Z ciekawszych prac dotyczących archiwów skarbowych w okresie staropolskim można wymienić: P. Bańkowski, Archiwum Kameralne i jego losy, Archeion, t. 17, 1948, s. 113-143; J. Karwasińska, Archiwa skarbowe dawnej Rzeczypospolitej, [w:] Straty archiwów i bibliotek warszawskich w zakresie rękopiśmiennych źródet historycznych, t. 1, Archiwum Główne Akt Dawnych, Warszawa 1957, s. 70-124; taż, Archiwum Skarbowe Koronne i Obojga Narodów, Rocznik Komisji Historycznej TNW, t. 1, 1929, z. 2, s. 1-30; 
przy urzędzie marszałkowskim działała odrębna kancelaria, po której pozostały dwa archiwa w postaci tak zwanego Archiwum Marszałkowskiego Sądowego oraz Archiwum Marszałkowskiego Ekonomicznego ${ }^{2}$. Najbardziej liczna rzesza urzędników była jednak zatrudniona w kancelarii królewskiej - na jej czele stali kanclerz wielki koronny (kancelaria większa) oraz podkanclerzy (kancelaria mniejsza). Działalność obu kancelarii znalazła odbicie w aktach Archiwum Koronnego Krakowskiego, Archiwum Koronnego Warszawskiego oraz Archiwum Metryki Koronnej ${ }^{3}$.

Nie można jednak zrzucać odpowiedzialności za brak wykształcenia się stale funkcjonującej, jednej kancelarii, obsługującej działalność kolejnych hetmanów koronnych, tylko i wyłącznie na czynnik późnego ukonstytuowania się hetmaństw jako stałych urzędów. Zaprzecza temu powstanie w drugiej połowie XVII w. Archiwum Generałów Artylerii Koronnej4. Przy urzędzie generała artylerii koronnej, powołanym do życia w 1646 r. przez Władysława IV, do końca XVIII w. narosło przecież spore archiwum.

A. Kłodziński, O Archiwum Skarbca Koronnego na zamku krakowskim, Archiwum Komisji Historycznej PAU, seria 2, t. 1, 1923, s. 258-289; A. Pawiński, Skarbowość w Polsce i jej dzieje za Stefana Batorego, Warszawa 1881 (Źródła Dziejowe, t. 8); A. Rybarski, Skarb i pieniądz za Jana Kazimierza, Michata Korybuta i Jana Sobieskiego, Warszawa 1939; J. Senkowski, Akta skarbowe Rzeczypospolitej, [w:] Archiwum Gtówne Akt Dawnych $w$ Warszawie. Przewodnik po zespotach, t. 1: Archiwa dawnej Rzeczypospolitej, Warszawa 1958 , s. 49-52.

2 Wybór literatury dotyczącej archiwów marszałkowskich: J. Jankowska, Akta Komisji Brukowej m. Warszawy 1743-1796, [w:] Straty archiwów i bibliotek, t. 1, s. 140-141; taż, Akta urzędu Marszatka Wielkiego Koronnego 1611-1794, [w:] Straty archiwów i bibliotek, t. 1, s. 132; taż, Akta Urzędu Marszatkowskiego Koronnego (1743) 1766-1794, [w:] Archiwum Gtówne Akt Dawnych w Warszawie. Przewodnik, t. 1, s. 297-300.

3 Spośród bogatej literatury dotyczącej archiwów koronnych i Metryki Koronnej można wymienić: A. Guliński, Historia Metryki Koronnej i Litewskiej, Kraków 1853; S. Kętrzyński, Uwagi o początkach Metryki Koronnej i jej charakterze w XVw., Archeion, t. 2, 1927, s. 1-30; A. Kłodziński, dz. cyt., s. 124-578; J. Siemieński, Ze studiów nad Archiwum Koronnym (z powodu monografii Abdona Ktodzińskiego), Przegląd Historyczny, t. 24, 1924, s. 141-186; I. Sułkowska, Archiwum Koronne, [w:] Archiwum Gtówne Akt Dawnych w Warszawie. Przewodnik, t. 1, s. 5-6; taż, Archiwum Koronne Krakowskie, [w:] Archiwum Gtówne Akt Dawnych w Warszawie. Przewodnik, t. 1, s. 6-16; Z. Wójcik, Archiwum Koronne Warszawskie, [w:] Archiwum Gtówne Akt Dawnych w Warszawie. Przewodnik, t. 1, s. 17-23; tenże, Uwagi archiwisty o Archiwum Koronnym Warszawskim, Archeion, t. 22, 1954, s. 88-102.

${ }^{4}$ O Archiwum Generałów Artylerii Koronnej pisali między innymi: B. Pawłowski, Militaria polskie $w$ warszawskich archiwach rzadowych, Bellona, t. 1, 1918, s. 670; A. Stebelski, Akta artylerii koronnej 1646-1791, [w:] Straty archiwów i bibliotek, t. 1, s. $168-171$. 
Istotny wpływ na charakter archiwów hetmańskich miał brak konkretnego określenia kompetencji urzędu do początku XVIII w. Sprecyzowały je dopiero bardziej szczegółowo postanowienia Sejmu Niemego z 1717 r. Było to przyczyną licznych konfliktów pomiędzy hetmanami a pozostałymi urzędnikami centralnymi. Można tu wymienić chociażby wspólny obszar działania hetmanów i kanclerzy w dziedzinie prowadzenia polityki zagranicznej (utrzymywanie poselstw, przyjmowanie obcych posłów, korespondencja dyplomatyczna) i konflikt hetmanów z podskarbimi na tle finansowania wojska. Wskutek tego w archiwach hetmańskich narastała między innymi dokumentacja, która w zasadzie powinna znaleźć się $\mathrm{w}$ archiwum koronnym bądź też podskarbińskim, a nie w prywatnym archiwum hetmańskim. Jednak właśnie brak sprecyzowanych kompetencji, a co za tym idzie - niezbyt jasne pojęcie o charakterze dokumentacji narastającej $\mathrm{w}$ archiwum hetmańskim przyczyniły się do akceptacji takiego stanu rzeczy przez czynniki rządzące.

Szeroki zakres uprawnień hetmaństw koronnych i litewskich, szczególnie hetmana wielkiego, również sprzyjał procesowi uprywatnienia dokumentacji z nimi związanej. Ich bardzo rozległe kompetencje wymykały się bowiem nierzadko kontroli społeczeństwa szlacheckiego. W dużym stopniu zwyczajowe, a nie prawnie opisane, kompetencje hetmanów nie znajdowały się z reguły w centrum uwagi społeczeństwa szlacheckiego. Oczywiście, o ile władza buławy nie ingerowała zbytnio w jego wolności.

Brak określenia konkretnych kompetencji związanych z hetmaństwem stawiał ten urząd niejako poza prawem. Hetmani nie podlegali bowiem kontroli żadnych instytucji państwowych. Najczęściej przedstawiali tylko ustne sprawozdania ze swoich działań przed królem, senatem lub izbą poselską. Działo się to oczywiście post factum wydarzeń, z których składali relacje. Wobec tego nie byli zobowiązani do dostarczania jakiejkolwiek dokumentacji związanej ze sprawowanym urzędem ${ }^{5}$. Ich akta były niejako wyłączone z publicznego obiegu i nie podlegały kontroli instytucji państwowych. Jako przykład owej prywatności archiwów hetmańskich, nawet w przypadku akt o zdecydowanie publicznym charakterze, może służyć sprawa dyplomu elekcyjnego, na mocy którego w $1610 \mathrm{r}$. syn Zygmunta III, Władysław Waza, został wybrany na wielkiego księcia mo-

5 Wiadomo jednak, że hetmani, występując przed sejmem i argumentując swoje posunięcia, przedstawiali niekiedy archiwalia ze swojego prywatnego archiwum. Uczynił tak na przykład hetman Stanisław Źółkiewski, który odpierając zarzuty, związane z zawarciem traktatu z Turkami pod Buszą, przedłożył „oryginały pism, powoływał się na instrukcje od króla”, zob. T. Korzon, Dzieje wojen i wojskowości w Polsce. Epoka przedrozbiorowa, t. 2, Kraków 1912, s. 198-199. 
skiewskiego. Główną osobą, prowadzącą pod Moskwą rokowania z duchowieństwem prawosławnym i bojarami, był Stanisław Żółkiewski, wówczas hetman polny koronny. Otóż po otrzymaniu owego dyplomu Żółkiewski przesłał go Zygmuntowi III Wazie, ten jednak dyplomu nie przyjął. Po 25 latach, kiedy posłowie moskiewscy w trakcie negocjacji zażądali od strony polskiej zwrotu owego dyplomu, okazało się, że nie jest znane miejsce jego przechowywania. Wśród osób, które mogły go posiadać, od 1610 r. wymieniano między innymi, obok kanclerza litewskiego Lwa Sapiehy i pisarza litewskiego Jana Druckiego Sokolińskiego, również spadkobierców Stanisława Żółkiewskiego ${ }^{6}$.

Z odmienną sytuacją można spotkać się w przypadku innych urzędów ministerialnych, na przykład podskarbich. Osoby sprawujące ten urząd często przechowywały w swoich prywatnych archiwach dokumentację urzędową. Jeżeli jednak przed śmiercią podskarbiego owe akta nie trafiły z powrotem do państwowego archiwum, wówczas proszono o ich zwrot jego spadkobierców. Świadczą o tym liczne konstytucje sejmowe?.

Bez wątpienia czynnikiem, który odegrał znaczącą rolę w dziejach archiwów hetmańskich, była duża mobilność hetmanów, zobowiązanych do częstego przebywania wraz z wojskiem z dala od prywatnych rezydencji. Szczególnie w XVI i XVII w. hetmani koronni, w związku z okresem ciągłych, długoletnich wojen, byli zmuszeni do mieszkania w obozie. Zmiany miejsca pobytu nie wpływały budująco na stabilność ich archiwów. Nie bez znaczenia był też fakt częstego przewożenia archiwum bieżącego przez poszczególnych hetmanów z jednego miejsca postoju na drugie. Poza tym dużo prostsze okazywało się składowanie akt hetmańskich w prywatnych siedzibach hetmanów, położonych zazwyczaj blisko teatrów działań wojennych, niż odsyłanie ich do Warszawy, gdzie znajdowała się od początku XVII w. większość archiwów koronnych.

Na pewno pośredni wpływ na prywatny charakter archiwów hetmańskich miała też znaczna grupa urzędników i dostojników wojskowych - przejmując część kompetencji hetmanów i współdziałając z nimi, wytwarzali oni własne archiwa, w których narastała dokumentacja związana ze sprawami organizacji i administracji wojska. To odciążenie hetmanów pociągało za sobą pewien spadek znaczenia akt w archiwach hetmańskich na korzyść archiwów ich pod-

${ }^{6}$ A. S. Radziwiłt, Pamiętnik o dziejach w Polsce, t. 1: 1632-1636, oprac. A. Przyboś, R. Żelewski, Warszawa 1980, s. 428.

7 Volumina Legum (dalej: VL), t. 7, wyd. J. Ohryzko, Petersburg 1860: Kwit sukcessorom W. niegdyś Ossolinskiego Podskarbiego Wielkiego Koronnego, s. 147; tamże, Kwit sukcessorom W. Iana Kantego Moszyńskiego Podskarbiego W. Koronnego; tamże, Kwit Sukcessorom zmarłych Podskarbich: Czapskiego y Grabowskiego, s. 148; tamże, Kwit W. Teodorowi Wesslowi Podskarbiemu Wielkiemu Koronnemu, s. 148. 
władnych, tym bardziej jeśli weźmie się pod uwagę fakt, że często były to akta o charakterze finansowym, a więc odnoszące się do kwestii najbardziej drażliwych w społeczeństwie szlacheckim. Dotyczy to przede wszystkim urzędu pisarza polnego koronnego, który przez długi czas odpowiadał za zgodność stanu liczebnego wojska $\mathrm{z}$ wydatkami państwa na jego utrzymanie.

Wydaje się, że społeczeństwo szlacheckie zwyczajowo nie przywiązywało wagi do dokumentacji powstającej w toku działalności osób sprawujących urząd hetmański. Wychodzono z założenia, że akta narastające w prywatnych archiwach hetmanów nie mają zbyt dużego znaczenia dla funkcjonowania państwa. Przy tym ich zawartość częściowo pokrywała się z treścią dokumentacji innych urzędów, gromadzonej w archiwach o charakterze publicznym. Dotyczyło to głównie spraw związanych z finansowniem wojska, które znalazły odzwierciedlenie na przykład w aktach Archiwum Podskarbińskiego czy Archiwum Skarbu Kwarcianego. Istotny dla uznania prywatności akt hetmańskich był przełom XVI i XVII w., kiedy to Jan Zamoyski i Stanisław Żółkiewski piastowali jednocześnie godności kanclerza i hetmana wielkiego koronnego. Ten blisko 30-letni okres dużego wpływu osób pełniących urząd hetmański na funkcjonowanie państwa przez kierowanie jego polityką zagraniczną i wewnętrzną oraz zarządzanie siłami zbrojnymi mógł wytworzyć w świadomości szlachty pogląd na pewien związek akt urzędu hetmańskiego z aktami kanclerskimi. Być może dlatego uznano niesłusznie, że akta hetmańskie pozostają, podobnie jak akta kanclerskie, w gestii instytucji o charakterze publicznym, a nie osób prywatnych. Można przypuszczać, że właśnie w początkowym okresie kształtowania się hetmaństw koronnych, to znaczy w XVI w., doszło do publicznej akceptacji prywatności ich archiwów. Trudno w tej chwili ustalić, czy w późniejszym czasie wysuwano jakieś bardziej kategoryczne żądania, mające na celu przejęcie dokumentacji narastającej w archiwach hetmańskich lub choćby uzyskanie prawa wglądu do niej przez instytucje publiczne. Nawet jeśli takie próby były podejmowane, można z całą pewnością stwierdzić, że nie przyniosły one żadnego rezultatu.

\section{ZASOBY ARCHIWÓW HETMAŃSKICH - RÓŻNICE}

Istotnym zagadnieniem $\mathrm{w}$ ramach charakterystyki archiwów hetmańskich jest określenie czynników oddziałujących na strukturę i wielkość ich zasobów. Bez wątpienia na proces tworzenia archiwów hetmańskich wpływały: długość sprawowania hetmaństwa, jego rodzaj (polne czy wielkie), uprawnienia urzędu hetmańskiego w okresie jego piastowania, a także ewentualne 
sprawowanie innych urzędów oraz funkcji jednocześnie z dzierżeniem buławy hetmańskiej. Do takich czynników należy zaliczyć również miejsce osób sprawujących władzę hetmańską w konkretnych realiach społeczno-politycznych, ich aktywność we wszystkich dziedzinach życia publicznego i prywatnego, a co za tym idzie - określenie ich pozycji wśród elity społeczeństwa szlacheckiego, odgrywającej inspirującą rolę w życiu społecznym i politycznym kraju. Nie można w końcu rozpatrywać archiwów hetmańskich w oderwaniu od realiów, w jakich kształtowały się powstające równolegle z nimi archiwa urzędów ministerialnych i archiwa rodowe.

Odrębna analiza każdego z wyżej wymienionych czynników mogłaby doprowadzić do bardzo mylących wniosków. Otóż biorąc pod uwagę tylko długość sprawowania hetmaństwa, można by wydzielić grupę hetmanów, którzy teoretycznie nie powinni byli pozostawić po sobie większej liczby akt związanych z dzierżeniem buławy. Najbardziej spektakularnym przykładem jest osoba Stefana Czarnieckiego, mianowanego hetmanem polnym koronnym 2 stycznia 1665 r., po odebraniu tego urzędu Jerzemu Sebastianowi Lubomirskiemu. Czarniecki jednakże nie cieszył się nową godnością zbyt długo, ponieważ zmarł już 16 lutego tego roku. Mikołaj Hieronim Sieniawski sprawował urząd hetmana polnego koronnego przez niecały rok (nominacja między 29 stycznia a 8 lutego 1683 r., zgon 15 grudnia 1683 r.). Podobnie Piotr Ożarowski, który piastował to stanowisko między 19/20 listopada 1793 a 9 maja 1794 r. Mikołaj Mielecki urząd hetmana wielkiego sprawował około roku (nominacja pod koniec 1578 lub na początku 1579 r., rezygnacja na początku 1580 r.). Niewiele ponad dwa lata urząd hetmana polnego sprawował Stanisław Chomentowski (w latach 1726-1728), ponad dwa i pół roku hetmanem polnym był zaś Stanisław Lanckoroński (1654-1657). Bez wątpienia archiwa pozostałe po Janie Klemensie Branickim (który urzędy hetmana polnego, a potem wielkiego sprawował łącznie przez 36 lat), Janie Amorze Tarnowskim (32 lata; w tym miejscu należy jednak przypomnieć, że Tarnowski kilkakrotnie zrzekał się hetmańskiej buławy) czy Stanisławie Koniecpolskim (28 lat sprawowania hetmaństwa) musiały siłą rzeczy zawierać większą liczbę archiwaliów związanych z piastowaniem godności hetmana.

Rodzaj sprawowanego hetmaństwa miał również istotne znaczenie dla wielkości i charakteru archiwum. Wynikało to z zasady podległości hetmana polnego hetmanowi wielkiemu. Hetman polny jako podwładny, ewentualnie zastępca hetmana wielkiego w razie jego nieobecności, czy to z powodu wakatu, czy wypadków losowych (choroba, wyjazd zagraniczny), miał o wiele mniejsze uprawnienia, w związku z tym liczba akt powstających w czasie jego urzędowania powinna być mniejsza od dokumentacji tworzącej archiwum hetmana wiel- 
kiego. Sytuacja była odmienna tylko wówczas, gdy hetman polny przez okres kilku-, czy nawet kilkunastoletni z powodu wakatu na urzędzie hetmana wielkiego praktycznie przejmował wszystkie jego obowiązki i prerogatywy. Jako przykład można podać osobę Stanisława Żółkiewskiego, który czekał na hetmaństwo wielkie, mimo śmierci Jana Zamoyskiego, kanclerza i hetmana wielkiego koronnego, w 1605 r., do 1618 r. Podobnie było w przypadku Stanisława Koniecpolskiego, który przez blisko 12 lat jako hetman polny samodzielnie sprawował władzę wojskową, a nominację na urząd hetmana wielkiego otrzymał dopiero w 1632 r., mimo że hetman wielki koronny Stanisław Żółkiewski nie żył już od $1620 \mathrm{r}$.

Następny czynnik, mający wpływ na charakter archiwów hetmańskich, to znaczenie urzędu hetmana w okresie sprawowania go przez daną osobę. Chodzi mianowicie o jego uprawnienia i obowiązki, o jego prawne opisanie. Czym innym było bowiem hetmaństwo Jana Amora Tarnowskiego w pierwszej połowie XVI w. czy Adama Mikołaja Sieniawskiego na początku XVIII w., czymś innym zaś hetmaństwo Franciszka Ksawerego Branickiego w drugiej połowie tego stulecia. Jak wiadomo, kompetencje i obowiązki urzędu hetmańskiego kształtowały się przez cały czas jego istnienia. Najpierw, do końca XVI w., hetmaństwo było traktowane jako funkcja $\mathrm{z}$ ogólnie sformułowanymi uprawnieniami i nałożonymi na nie obowiązkami. Koniec XVI i początek XVII w. w historii hetmaństwa charakteryzuje się jego prawnym ukonstytuowaniem, określeniem bardziej szczegółowych kompetencji i powinności. Następny okres do 1717 r., czyli do postanowień Sejmu Niemego, to z jednej strony próby ukrócenia jego kompetencji, z drugiej zaś walka hetmanów i ich frakcji o utrzymanie, a nawet poszerzenie zakresu władzy. Apogeum wpływu hetmanów na całokształt życia społecznego i politycznego Rzeczypospolitej nastąpiło w latach wojny północnej, szczególnie w jej początkowym okresie. Ograniczenia kompetencji hetmańskich postanowieniami z $1717 \mathrm{r}$. zdegradowały dosyć znacznie urząd hetmana, pozostawiając przy nim tylko część dawnych kompetencji. Powoływanie kolegialnych ciał w epoce stanisławowskiej, w których hetmani sprawowali w zasadzie jedynie funkcje ich przewodniczących, odsunęły osoby piastujące ten urząd od nieograniczonego wpływu na wojsko. W tym jednak czasie nastąpiła metamorfoza urzędu hetmańskiego - stał się on de facto urzędem politycznym. Taka sytuacja trwała do końca istnienia Rzeczypospolitej.

Ten nieco przydługi, acz - jak się wydaje - potrzebny wywód może tłumaczyć prostą zależność, w myśl której po hetmanie sprawującym urząd w okresie rozkwitu władzy hetmańskiej powinno pozostać dużo więcej akt niż po osobie piastującej ten sam urząd wówczas, gdy jego kompetencje były jeszcze niesprecyzowane lub ograniczone. 
Nieco mniej istotnym czynnikiem wpływającym na kształtowanie się zasobów archiwów hetmańskich było piastowanie równolegle $\mathrm{z}$ hetmaństwem innych urzędów i godności. Najbardziej oczywiste przykłady to jednoczesne sprawowanie przez Jana Zamoyskiego i Stanisława Żółkiewskiego urzędu hetmańskiego i kanclerskiego, przez Jerzego Sebastiana Lubomirskiego urzędu hetmana polnego i marszałka wielkiego oraz przez Jana Sobieskiego urzędu hetmana i marszałka wielkiego. Równoczesne sprawowanie przez tą samą osobę dwóch tak istotnych urzędów, jak kanclerstwo i hetmaństwo, musiało znaleźć odbicie w pozostawionych przez nią archiwaliach. Nie znając szczegółowego zakresu kompetencji hetmaństwa, trudno jednoznacznie określić, jakie akta wpływały do archiwum tej osoby z racji sprawowania władzy hetmańskiej, a jakie $\mathrm{z}$ racji piastowania chociażby urzędu kanclerskiego ${ }^{8}$. Jak już wyżej wspomniano, doszło bowiem do częściowego przejęcia przez hetmanów uprawnień dyplomatycznych, przysługujących zasadniczo kanclerzom. Podobnie, choć w nieco mniejszym zakresie, dotyczy to sprawowania innych urzędów i godności.

Kolejnym bardzo ważnym wyznacznikiem charakteru archiwów hetmańskich była pozycja osoby sprawującej urząd hetmana wśród elit społeczeństwa szlacheckiego. Zależała ona przede wszystkim od aktywności we wszelkich dziedzinach życia społecznego, nie tylko w polityce, ale również w gospodarce, kulturze oraz życiu codziennym. Oczywiście, ta pozycja była bardzo mocno uzależniona od aktualnej sytuacji społeczno-politycznej. Nieprzypadkowo chyba najbardziej znanymi hetmanami koronnymi są: Jan Zamoyski, Stanisław Źółkiewski, Stanisław Koniecpolski, Stefan Czarniecki, Sebastian Jerzy Lubomirski, Jan Sobieski i Jan Klemens Branicki. Wszystkim im przyszło sprawować urząd hetmański w latach, w których miały miejsce bardzo istotne wydarzenia polityczne, nierzadko o wydźwięku europejskim. Nie ulega wątpliwości, że najważniejszą cechą wyróżniającą tych hetmanów była ich postawa jako dowódców wojskowych, choć w przypadku Jana Klemensa Branickiego trudno mówić o jakichś szczególnych osiągnięciach w tej dziedzinie. Aktywność wymienionych osób na polu militarnym musiała zaznaczyć się w ich archiwach większą ilością dokumentacji związanej ze sprawowaniem władzy hetmańskiej. Z kolei popularność hetmanów w społeczeństwie szlacheckim przysparzała im licznej klienteli, wśród której znajdowały się nawet jednostki sprawujące najwyższe urzędy i funkcje w kraju. W ten sposób tworzył się bardzo szeroki krąg informa-

8 Próby wydzielenia archiwaliów proweniencji państwowej z Archiwum Zamoyskich przechowywanego w Archiwum Głównym Akt Dawnych dokonała Teresa Zielińska, zob. T. Zielińska, Zbiory archiwalne ordynatów Zamoyskich jako skarbnica dokumentów państwowości polskiej, Miscellanea Historico-Archivistica, t. 6, 1994, s. 173-223. 
torów hetmańskich. Ich meldunki, raporty czy listy były nadsyłane do hetmanów w bardzo dużej liczbie. Tematyka w nich poruszana była różna, dotyczyły one m.in. spraw wojskowych.

Omawiając archiwa poszczególnych hetmanów, należy uwzględnić również okres, w którym piastowali oni swój urząd. Można bowiem założyć, że akta związane ze sprawowaniem hetmaństwa z archiwum Stanisława Żółkiewskiego, zajmującego w latach 1588-1618 stanowisko hetmana polnego, a w latach 1618-1620 hetmana wielkiego, były liczniejsze niż akta związane ze sprawowaniem hetmaństwa polnego w latach 1633-1636 przez Marcina Kazanowskiego. Hetmani czasów wojen, napiętej sytuacji politycznej, gromadzili zapewne dużo więcej dokumentacji w archiwach niż ci, którzy piastowali urząd w okresach politycznej i militarnej stabilizacji.

W końcu trzeba wziąć pod uwagę zmiany zachodzące w zasobie aktowym archiwów hetmańskich w związu ze swego rodzaju biurokatyzacją życia politycznego i społeczno-gospodarczego, obejmującą swoim zasięgiem również sity zbrojne. O ile dla XVI i XVII w. dokumentacja archiwalna gromadzona w archiwach hetmanów była dosyć jednorodna pod względem treści i formy, a dodatkowo niezbyt liczna, o tyle w XVIII w. nastąpił olbrzymi rozkwit zasobów tych archiwów. Ten proces jest szczególnie zauważalny od lat trzydziestych XVIII w., kiedy to w archiwach hetmańskich zaczęła pojawiać się masa różnego rodzaju raportów, sprawozdań i jednolitych pod względem formy wykonania i zawartych treści tabel.

Odrębnym zagadnieniem, związanym jednak mocno z charakterem archiwów hetmańskich, jest problem ich postrzegania przez instytucje publiczne i osoby prywatne, współczesne czasom, w których te archiwa powstawały, a następnie stawały się fragmentami większych archiwów rodowych lub rodzinnych. Innymi słowy, czy te akta były traktowane jako archiwalia o charakterze publicznym, czy też widziano w nich własność prywatną hetmanów. Można wysunąc przynajmniej dwa argumenty na uzasadnienie tezy o publicznym charakterze archiwów hetmańskich: fakt ich narastania przy osobach sprawujących jeden z najbardziej prestiżowych urzędów w państwie oraz bardzo szeroki zakres władzy hetmańskiej. Jednak argumenty, przemawiające za prywatnością archiwów hetmańskich, były mocniejsze. Przede wszystkim archiwa pierwszych hetmanów zXVI w. były najprawdopodobniej bardzo niewielkie pod względem zasobu, na który składała się głównie korespondencja z królem, najwyższymi urzędnikami i dostojnikami w państwie oraz pozostałymi osobami związanymi z hetmanami zależnościami wojskowymi i prywatnymi. Obok korespondencji niezbyt licznie występowały różnego rodzaju zestawienia i inwentarze żołnierzy i sprzętu wojskowego. Jak już wcześniej wspomniano, dosyć późne ukształto- 
wanie się urzędu hetmańskiego i precyzowanie jego kompetencji na podstawie zwyczajowej, a nie prawnej, rzutowało początkowo na uznawanie hetmaństwa przez społeczeństwo szlacheckie za doraźną funkcję. Wobec tego zapewne uważano, że dokumentacja narastająca przy hetmanach nie ma zbyt dużego znaczenia. W późniejszym zaś czasie prywatny charakter archiwów hetmańskich został usankcjonowany prawem zwyczajowym, które odgrywało w Rzeczypospolitej nie mniejszą rolę niż prawo stanowione.

\section{TyPologia DOKUMENTACJI WYSTĘPUJĄCEJ W ARCHIWACH HETMAŃSKICH}

W archiwach hetmanów koronnych zachowała się dokumentacja archiwalna różnorodna zarówno pod względem formalnym, kancelaryjnym, jak i merytorycznym. Nie dziwi to jednak, jeśli weźmie się pod uwagę wielokierunkowość kompetencji związanych z hetmaństwem. Długi okres kształtowania się hetmaństw koronnych oraz zmiany w ich uprawnieniach zadecydowały o tym, że nie można spodziewać się występowania w archiwum Jana Zamoyskiego takiej samej dokumentacji jak w archiwum Mikołaja Sieniawskiego czy Jana Klemensa Branickiego. Różne były bowiem prerogatywy urzędu hetmańskiego w XVI w., a zupełnie inne w połowie XVIII w. Nie można także pominąć aspektu rozwoju administracji państwa, zasad komunikowania się, ogólnego poziomu wykształcenia społeczeństwa szlacheckiego czy w końcu stanu biurokratyzacji życia społecznego.

Pierwsze kryterium, za pomocą którego można podzielić dokumentację występującą w archiwach hetmańskich, to jej postać kancelaryjna. Tutaj zdecydowanie na pierwsze miejsce wysuwa się korespondencja, następnie zestawienia tabelaryczne, akta spraw, księgi, w końcu dokumenty. Jest rzeczą niemożliwą ustalenie procentowej wielkości poszczególnych rodzajów archiwaliów w archiwach hetmańskich, gdyż była ona na pewno różna w zależności od okresu, w jakim sprawowano hetmaństwo. Wydaje się jednak, że zawsze dużą grupę stanowiła korespondencja, a w XVIII w. zestawienia tabelaryczne.

Inne kryterium, jakie można zastosować przy klasyfikacji hetmańskich archiwaliów, to zasada przynależności kancelaryjnej. Według niej można wyróżnić archiwalia, które trafiły do archiwum z zewnątrz, a ich adresatem był hetman, ewentualnie osoby blisko z nim związane (chociażby pracownicy kancelarii). Drugą grupę stanowią archiwalia wytworzone przez hetmana lub jego otoczenie. Należy tu rozróżnić te wytworzone na użytek własny hetmana oraz te skierowane do osób trzecich. W końcu do trzeciej grupy archiwaliów należy 
zaliczyć akta pochodzenia obcego. Konkretnie chodzi o dokumentację, która ani nie była wytworem kancelarii hetmańskiej, ani nie była skierowana bezpośrednio do hetmanów.

Kolejnym kryterium jest zasada przedmiotowości zasobów archiwów hetmańskich, wynikająca z funkcji hetmanów koronnych. Tę dokumentację można podzielić na dokumentację o charakterze wojskowym, finansowym, sądowniczym, dyplomatycznym oraz prywatnym (to znaczy odnoszącą się bezpośrednio do osoby hetmana, związaną jednak również ze sprawowanym urzędem, np. akty nominacyjne na urzędy hetmańskie, dokumentacja związana $\mathrm{z}$ ich uposażeniem, korespondencja).

Biorąc pod uwagę kryterium formalne, postać fizyczną, pod jaką występuje w chwili obecnej dokumentacja z archiwów hetmańskich, można spotkać się z aktami luźnymi, klejonymi i zszywanymi. Oczywiście, wszystkie wyżej wymienione formy występowały również ówcześnie, choć wiadomo, że nie zawsze forma obecna jest formą oryginalną. Pierwotnie dokumentacja miała najczęściej postać luzów, które łączono w wiązki i fascykuły.

Charakterystyka dokumentacji przechowywanej w zasobach archiwów hetmanów koronnych zostanie dokonana na podstawie kryterium przedmiotowości. Wyjątkiem będzie odrębne omówienie grupy archiwaliów dotyczących przybocznych oddziałów hetmańskich ze względu na ich specyfikę oraz znaczną liczbę tego rodzaju dokumentacji w porównaniu do pozostałej części zasobu.

\section{DOKUMENTACJA WOJSKOWA}

Najliczniejszą grupę archiwaliów w zasobach archiwów hetmańskich stanowi obecnie dokumentacja związana z władzą administracyjno-wojskową hetmanów. Podstawową grupą wśród tych archiwaliów są różnego rodzaju raporty wojskowe mówiące o stanie osobowym poszczególnych oddziałów, uzbrojeniu, wyposażeniu technicznym, w końcu o wynagrodzeniu. W archiwum Jana Zamoyskiego, najlepiej zachowanym najstarszym archiwum hetmana koronnego, ten typ dokumentacji jest reprezentowany jeszcze niezbyt licznie. Archiwalia te narastały głównie w okresach działań wojennych, a więc również zwiększonej aktywności hetmanów. Najwięcej tego rodzaju akt zachowało się z czasów wojny Rzeczypospolitej z Moskwą w latach 1579-1582 oraz wojny ze Szwecją o Inflanty. Można tu wymienić regestry zawierające liczbowe zestawienia rotmistrzów, pocztów w chorągwiach i rotach czy stany osobowe załóg stacjonujących w garnizonach. Jako przykłady można przytoczyć wykaz rotmistrzów 
służących na Podolu w latach $1577-1578^{9}$, regestr piechoty służącej w Wielkim Księstwie Litewskim w 1578 r. ${ }^{10}$, listę hajduków biorących udział w oblężeniu Połocka w 1579 r. ${ }^{11}$, regestr roty Janusza Horwatha dokonany pod Pskowem 30 sierpnia 1582 r. $^{12}$, regestr roty strażnika koronnego Jana Zamoyskiego z 1 listopada $1600 \mathrm{r} \cdot{ }^{13}$ czy w końcu stan załogi stacjonującej w zamku derpskim z lat osiemdziesiątych XVI w. ${ }^{14}$

Inną grupą zestawień stanu osobowego wojsk są spisy nowozaciężnych żołnierzy, np. „,regestr przyjmowania żołnierzów na potrzebę wojenną do Moskwy” z 1581 r. ${ }^{15}$ oraz lista puszkarzy zaciągniętych w Gdańsku w 1601 r. na wyprawę inflancką ${ }^{16}$. Do tej grupy dokumentacji można również zaliczyć archiwalia związane z zaopatrzeniem wojska w sprzęt, żywność oraz z jego wynagrodzeniem. W archiwum Zamoyskiego znajdują się między innymi: zestawienie artylerii z okresu wojny inflanckiej ${ }^{17}$ oraz zapotrzebowanie na wojsko i sprzęt wojenny do Inflant z $1601 \mathrm{r}^{18}$ Należy przypuszczać, że większość tego rodzaju spisów służyła doraźnym celom, związanym głównie ze sprawami finansowania oddziałów zaciężnych ${ }^{19}$. Wynika to chociażby z zestawień zawierających obok liczbowych wykazów żołnierzy także informacje na temat długości pełnienia przez nich służby ${ }^{20}$. Trzeba jednak zwrócić uwagę, że w XVI w. hetmani nie mieli uprawnień finansowych. $Z$ racji sprawowania naczelnego dowództwa byli jedynie zainteresowani systematycznym wypłacaniem należności wojsku. Niedopełnienie tej formalności automatycznie stwarzało możliwość osłabienia sił zbrojnych podległych hetmanom w związku z porzuceniem służby przez nieopłaconych żołnierzy.

Można uznać z całą pewnością, że w XVII w., mimo że z tego okresu nie zachowało się zbyt dużo archiwaliów proweniencji hetmańskiej, akta o charakterze zestawień stanów osobowych formacji wojskowych i ich wyposa-

9 Archiwum Główne Akt Dawnych w Warszawie (dalej: AGAD), Archiwum Zamoyskich 1155-1938 (dalej: AZ), sygn. 3112, k. 1-2.

10 Tamże, k. 2-3.

11 Tamże, k. 4.

12 Tamże, k. 21-22.

13 Tamże, sygn. 38, s. 38-39.

14 Tamże, sygn. 3112, k. 39-42.

15 Tamże, k. 17-18.

16 Tamże, sygn. 38, s. 87.

17 Tamże, sygn. 3112, k. 13-14.

18 Tamże, k. 94-95.

19 Szerzej to zagadnienie omawia M. Plewczyński, Żotnierz jazdy obrony potocznej za panowania Zygmunta Augusta, Warszawa 1985.

20 AGAD, AZ, sygn. 3112, k. 81-82. 
żenia w sprzęt nadal stanowiły poważny fragment zasobów archiwów hetmańskich. Hetmani, jako naczelni wodzowie, byli zainteresowani wielkością i składem osobowym podporządkowanych im wojsk. Dlatego też oczywiste jest to, że w ich ręce trafiał ten rodzaj dokumentacji archiwalnej. Pod względem formalnym nie odbiegał on najprawdopodobniej od zestawień z XVI w. Porównując archiwalia tego typu w archiwum hetmańskim z końca tego stulecia (archiwum Jana Zamoyskiego) oraz archiwum hetmańskiego z początku XVIII w. (archiwa Mikołaja Hieronima Sieniawskiego i Stanisława Mateusza Rzewuskiego), można zaryzykować twierdzenie, że ewolucja zarówno w tematyce, jak i formie zewnętrznej akt nie przybrała jakiegoś znaczącego rozmiaru. Oczywiście, pewne istotne zmiany są widoczne, choć mają one raczej charakter ilościowy niż jakościowy. To zjawisko wynikało ze stałości kompetencji urzędu hetmańskiego, przynajmniej w sprawach administrowania wojskiem. Wzrost liczby wytwarzanej dokumentacji następował wraz z powiększeniem liczby oddziałów podległych hetmanom w związku z licznymi działaniami wojennymi prowadzonymi w XVII i na początku XVIII w. Zachowane $\mathrm{w}$ archiwach i bibliotekach akta o charakterze wojskowym najczęściej mają właśnie postać regestrów i rolli. Jako przykład może tu posłużyć materiał archiwalny z drugiej połowy XVII w., związany z kompanią husarską najpierw wojewody kijowskiego, później królewicza Jakuba Sobieskiego, w końcu samego Jana III Sobieskiego ${ }^{21}$. Składają się nań między innymi: specyfikacja szwadronów prawego i lewego skrzydła, komput wojsk polskiego i cudzoziemskiego autoramentu ustanowiony na sejmie w 1673 r., kwartalne, imienne zestawienia kompanii husarskiej, wyszczególniające towarzyszy w niej służących wraz z liczbą koni. Podobne archiwalia występują również w archiwum pozostałym po pułkowniku Marcjanie Ściborze Chełmskim, oboźnym wielkim koronnym z drugiej połowy XVII w. Jest to między innymi księga w formie dutki, zawierająca rolle regimentu dragońskiego, którego Chełmski był dowódcą ${ }^{22}$. W końcu przykład najbliższy archiwum hetmańskiemu, mianowicie rolle regimentu pieszego hetmana polnego koronnego Jerzego Lubomirskiego ${ }^{23}$.

${ }^{21}$ Biblioteka Zakładu Narodowego im. Ossolińskich we Wrocławiu (dalej: Ossol.), sygn. 11 906/III, s. 1-5, 9-12, 13-14.

22 Tamże, sygn. 1180/III, m.in. papiery wojskowe Marcjana Ścibora Chełmskiego, pułkownika i oboźnego wielkiego koronnego.

23 AGAD, Archiwum Radziwiłłów z Nieborowa [1347] 1427-1945 (dalej: AR), Dział VII, sygn. 224, Rolle regimentu pieszego Jerzego Lubomirskiego, a później Michała Kazimierza Radziwiłła. 
W archiwum Adama Mikołaja Sieniawskiego znajdują się odpowiedniki szesnastowiecznych regestrów, spisów i inwentarzy oddziałów wojskowych, uzbrojenia i sprzętu. Niektóre z nich mają już nieco inny wygląd pod względem formalnym, gdyż przybierają postać tabelaryczną, która w późniejszym czasie przekształci się w znormalizowane formularze. Nadal jednak występują również proste spisy nieodbiegające pod względem treści i formy zewnętrznej od swoich poprzedników z XVI w. Za przykład mogą posłużyć tabele regimentów arkebuzerii hetmanów wielkiego i polnego koronnych z 1708 r. ${ }^{24}$ czy specyfikacje innych oddziałów ${ }^{25}$.

Okresem, od którego datuje się istotny wzrost dokumentacji archiwalnej narastającej w archiwach hetmańskich, był przełom XVII i XVIII w. Wydaje się, że duże znaczenie miał moment objęcia tronu w Polsce przez Augusta II Sasa. Wraz z nowym władcą na dwór królewski przybyła liczna rzesza osób związanych dotychczas z saksońskim aparatem państwowym, tak bardzo przecież różnym od systemu administracji państwowej Rzeczypospolitej. Wśród urzędników saskich, którzy zjawili się w Polsce, znalazła się również grupa zawodowych wojskowych - obejmując komendę nad częścią wojska, tak zwanym cudzoziemskim autoramentem, wprowadzali oni doń metody organizacyjne armii saskiej. Ten proces był szczególnie zauważalny od 1710 r., kiedy to August II próbował wzmocnić wojska cudzoziemskiego autoramentu, obsadzając ich kadrę dowódczą oficerami obcego pochodzenia ${ }^{26}$.

W 1717 r., w związku z reorganizacjami zachodzącymi w wojsku, których konsekwencję stanowiło poważne ograniczenie uprawnień władzy hetmańskiej i ustalenie stałego komputu wojsk narodowego i cudzoziemskiego autoramentu w Koronie i na Litwie, doszło również do reorganizacji wewnętrznej wojska przez określenie zasad jego funkcjonowania w stosownych regulaminach. Owe przepisy wojskowe normujące organizację i funkcjonowanie poszczególnych oddziałów nakładały na nie między innymi obowiązek prowadzenia różnego rodzaju dokumentacji. „Objaśnienia Regulaminu Wojska Pieszego Koronnego 1717 Anni” określały precyzyjnie, jaka dokumentacja miała powstawać w konkretnych regimentach i chorągwiach.

Wszystkie księgi regimentowe nie tylko powinny znajdować się u komendanta regimentu i regimentskwatermistrza, lecz każde zakończenie rachunków regimentowych szefowi przysłane w dobrym u niego schowaniu zostawać ma. Wszystkie dokumenty

${ }^{24}$ Muzeum Narodowe, Biblioteka Czartoryskich w Krakowie (dalej: BCz), sygn. $2648 \mathrm{IV}$, s. 63, 65.

${ }^{25}$ Tamże, sygn. 2634 IV.

26 J. Wimmer, Wojsko Rzeczypospolitej w dobie wojny pótnocnej, Warszawa 1956, s. 430. 
publiczne, rachunki i korespondencje regimentowe, na których bardzo wiele należy, powinny być przekopiowane, z oryginałami przez kilku oficerów z regimentu, skonfrontowane, podpisane i zapieczętowane na pewnym miejscu dysponowane, od zguby zachowane były. Jeśli chodzi o tabele, rejestry miesięczne i extrakty do nich należące, każdy regiment tabelę miesięczną, modeluszem niżej podanym z rotą przysięgi na ostatku dołożoną, przez wszystkich sztabsoficerów z regimentu podpisaną, wespół z extraktami ubytku i przybytku ludzi, królowi, hetmanowi, szefowi wojska cudzoziemskiego zaciągu oraz inspektorowi wojskowemu ultimis każdego miesiąca, punktualnie odesłać powinien nie tylko dla informacji wiele jest żołnierzy znajdujących się w gotowości do służby, ale też i na pokazanie pieczołowitości około konserwacji każdego w ogólności i w szczególności ${ }^{27}$.

W archiwach hetmańskich opócz dotychczasowych, prostych pod względem formy i zawartości zestawień pojawiły się więc znormalizowane raporty. W późniejszym czasie kwestię obowiązkowego ich składania hetmanom normowały nawet ustawy sejmowe, chociażby z 1765 r. „Dozwolenie Prerogatyw Hetmanom teraźniejszym oboyga narodów”28, ustawa z 1768 r. „Kommisye Woyskowe oboyga narodów”29 czy ustawy z 1775 r.: „Powinności generał-lieutnanta”30, „Powinności generała-majora”31 oraz „Powinności Generała Artylerii”32.

Utworzenie urzędu generalnego inspektora armii w 1717 r. miało również istotny wpływ na wzrost dokumentacji narastającej w archiwach hetmańskich. Wiązało się to z główną funkcją inspektorów, którą była lustracja, przynajmniej raz w roku, wszystkich jednostek cudzoziemskiego autoramentu. Przez owe inspekcje, w czasie których generał inspektor kontrolował między innymi dokumentację lustrowanych jednostek, wymuszał na ich dowódcach obowiązek regularnego składania pisemnych sprawozdań u zwierzchników, w tym również hetmanów. Ponadto sam generalny inspektor był zobowiązany do przedstawiania po takiej lustracji dokładnego raportu hetmanowi, w którym zawierał propozycje usunięcia ewentualnych niedociągnięć. Jak się wydaje, do zadań inspektorów generalnych należało też opracowywanie schematów raportów i sprawozdań składanych przez dowódców poszczególnych oddziałów. Między innymi w jednym $\mathrm{z}$ listów adresowanych do hetmana wielkiego koronnego Jana Klemensa Branickiego wojewoda rawski i zarazem generalny inspektor wojsk

27 Archiwum Państwowe w Krakowie (dalej: AP w Krakowie), Archiwum Sanguszków 1284-1945 [2000]: Archiwum Podhoreckie II (dalej: APd II), sygn. 263.

${ }^{28}$ VL, t. 7, s. 205.

29 Tamże, s. 315.

${ }^{30}$ VL, t. 8, wyd. J. Ohryzko, Petersburg 1860, s. 102-103.

31 Tamże, s. 103-104.

32 Tamże, s. 102. 
koronnych Kazimierz Granowski powiadamiał hetmana, że opracował nowy schemat raportów miesięcznych ${ }^{33}$. Branicki przykładał dużą wagę do dobrej współpracy z generalnym inspektorem. Świadczy o tym „Regulamen Generalny Regimentu Pieszego Najjaśniejszej Królowej Jej mci”, przygotowany najprawdopodobniej w kancelarii hetmańskiej Jana Klemensa Branickiego. Otóż w punkcie poświęconym lustracji regimentów wspomniano, że komendanci i oficerowie dopuszczali się nadużyć i oszustw, najczęściej polegających na zawyżaniu stanu liczbowego oddziałów. Aby temu zapobiec:

więc z tych i innych przyczyn Monatstabelle z przychodem i odchodem effective z monatslisty, specyfikacje urlopowanych, extrakty wszelkich ordynansów według schemmatów, które do Regimentu wydane będą co miesiąc Generał Inspektorowi Regimenta odsyłać mają, aby przy lustracji mógł konfrontować i inwestygować, jeżeli Raporty mnie odsyłane były rzetelne i jeżeli tak się effective Regiment znajdował, jak którego miesiąca z raportem był mi podany, wszelkie ordynanse i dyspozycje moje Hetmańskie do Regimentu przysłane, jeżeli instantaneam dla siebie miały executionem, i Szeff lub kommendant Regimentu w approbowaniu krixrechtów, w dawaniu officerskich Patentów więcej sobie nie pozwolił nad to, co mu z władzy i dyspozycji mojej hetmańskiej in scripto jest akorodowano ${ }^{34}$.

Bardzo ciekawym dokumentem dotyczącym składania różnego rodzaju raportów przez wojskowych było pismo hetmana wielkiego koronnego Franciszka Ksawerego Branickiego, datowane w Warszawie 23 kwietnia 1775 r. $^{35}$, a więc wystawione w okresie konfliktu Branickiego z Komisją Wojskową, dotyczące-

33 AGAD, Archiwum Roskie 1372-1911 (dalej: ARo), Korespondencja, pudło 7/29, s. 86 .

34 Tamże, Militaria, pudło 6, Regiment pieszy królowej, plik 1, s. 36. W owym regulaminie znajduje się także rozdział „O Xięgach Regimentowych i Kompanicznych”, w którym są wymienione wszystkie akta, jakie miał prowadzić każdy regiment i kompania. Były to księgi: rachunków, płac, generalnego przychodu pieniędzy, wielkiego i małego moderunku, broni, lederwerku, namiotów i innych rekwizytów. Dodatkowo oddziały były zobowiązane do prowadzenia tzw. żurnala rozkazów (befelów), sztam-, lenunx- i vacansbuchów, książeczki obrachunkowej kapitana z podoficerami i żołnierzami. Ponadto zawarto w nim również zestawienie raportów, jakie miały być wysyłane do hetmana: „miesięczne Tabelle z przychodem i odchodem effective sztaabs i oberofficerów, Monats Revisions, Conduit Listy, Tabelle Kadetów, Inwalidów, specyfikacje urlopowanych, ekstrakty ordynansów”, do których schematy za zgodą hetmana przygotował Generalny Inspektor. Natomiast archiwum regimentowe powinno być zabezpieczone w formie sumariusza sporządzonego na podstawie akt, zob. tamże, s. 40.

35 AP w Krakowie, Archiwum Sanguszków 1284-1945 [2000]: Archiwum Podhoreckie hr. Andrzeja Potockiego (dalej: APhAP), sygn. IX 3/48. 
go złożenia przez wojsko przysięgi na wierność hetmanowi. W owym piśmie jest podany schemat formularza raportu, jaki mieli składać komendanci korpusów od całej swojej komendy oraz szefowie i komendanci poszczególnych regimentów, a ponadto jest w nim zawarta instrukcja określająca szczegółowo sporządzenie raportu. Otóż raporty miały być zawsze pisane na arkuszu złożonym w kolumnę, na pierwszej połowie od prawej strony u góry należało wpisać tytuł dokumentu „Powinny Rapport”, a poniżej wypunktować jego zawartość „w krótkich i zrozumiałych expresiach”. U dołu pisma musiała znaleźć się data i podpis osoby przygotowującej raport. Hetman lub inna osoba, do której adresowano sprawozdanie, była zobowiązana do jego przepisania, czyli sporządzenia kopii o identycznej z oryginałem treści i formie, oraz do wpisania na jej drugiej wolnej kolumnie swoich rezolucji, z datą ich sporządzenia i podpisem. Natomiast oryginał z adnotacją „Resolutio dane” miał pozostawać w archiwum hetmańskim.

Z zasobów archiwów hetmańskich wyraźnie wynika, że postanowienia wyżej cytowanego regulaminu były poważnie traktowane przez osoby uprawnione do prowadzenia dokumentacji. Świadczą o tym liczne usprawiedliwienia wyższych oficerów, kierowane do hetmanów, w których wyjaśniali przyczyny zwłoki w nadesłaniu okresowych sprawozdań. Generał lejtnant Goltz w raporcie powinnym do hetmana polnego koronnego Seweryna Rzewuskiego tłumaczył się z niewysłania tabel miesięcznych tym, że nie otrzymał ich od swoich podwładnych. Chcąc zapobiec w przyszłości tego rodzaju opóźnieniom, Goltz wydał ordynans do wszystkich regimentów, aby wysyłały do niego tabele bez jakichkolwek wymówek, każdego pierwszego dnia miesiąca ${ }^{36}$. W podobnym tonie tłumaczył się Piotr Ożarowski, który pisał do Seweryna Rzewuskiego: „Nie mogąc się doczekać tabell miesięcznych od korpusów w Dywizji mojej będących, mianowicie Tabelli Brygady W. Walewskiego y Regimentu JW. Wodzickiego, z przyczyny, iż w ustawicznym transmarszu, niżeli przyjdzie mi przesłać Tabellę Dywizionalną tym czasem przesyłam Garnizonu Warszawskiego"37.

W pierwszej połowie XVIII w. w związku ze zmianami w organizacji sił zbrojnych Rzeczypospolitej pojawiła się w archiwach hetmańskich bardzo duża liczba dokumentacji o charakterze sprawozdawczym zarówno w formie opisowej, jak i tabelarycznej, do której należy zaliczyć: rolle lenungowe, ranglisty, tabele starszeństwa, raporty miesięczne, raporty powinne, sztamlisty, monatslisty i inne. Zawierały one bardzo różnorodne informacje. Najbogatszy w treść był formularz wprowadzony w kwietniu 1775 r. przez hetmana wielkiego Francisz-

\footnotetext{
36 Tamże, sygn. IX 3/53.

37 Tamże, sygn. X 1/27.
} 
ka Ksawerego Branickiego, który wydał rozkaz ujednolicenia formularzy raportów przysyłanych przez oddziały wojska koronnego ${ }^{38}$. Zasadniczo opracowano go z myślą o dużych oddziałach - korpusach. Jednakże miał on być wykorzystywany również przez oddzielnie stacjonujące regimenty. Na informacje zawarte w tak przygotowanym formularzu składała się: liczba żołnierzy znajdujących się aktualnie w korpusie (regimencie) z wyszczególnieniem: oficerów sztabowych (sztabsoficerów), untersztabu, oficerów, podoficerów (unteroficerów), felczerów (feldscherów), trębaczy i doboszy (fajfrów i doboszów), zwykłych żołnierzy (gemeinów). Następna grupa informacji dotyczyła ewentualnych braków w stanie oddziału. W formularzu przewidziano braki stanu osobowego spowodowane: odkomenderowaniem z oddziału do innej miejscowości, urlopowaniem, chorobą, aresztem, zgonem, abszytem (zwolnieniem), dezercją. Umieszczono też kilka tabel na informacje o liczbie woźniców, koni pociągowych, o prowiancie i furażu, o liczbie nowo zwerbowanych żołnierzy. Ostatnia grupa informacji odnosiła się do stanu koni w kawalerii z określeniem liczby koni znajdujących się poza oddziałem i niezdolnych do służby. Wszystkie dane miały być zestawione dla poszczególnych regimentów tworzących korpus. Pod formularzem na tej samej stronie miały znajdować się informacje zamieszczone dodatkowo. Na przykład, kiedy zachodziła konieczność odkomenderowania kogoś z oddziału, należało podać miejsce i cel odkomenderowania. W przypadku aresztu należało podać przyczynę i czas aresztowania żołnierza, natomiast w przypadku urlopu - miejsce przebywania urlopowanego, termin urlopu i nazwisko osoby go udzielającej. W niektórych sprawozdaniach występowały nawet informacje o warunkach fizycznych żołnierzy, ich wieku, narodowości, stanie cywilnym oraz wyznaniu ${ }^{39}$.

Inną formą dokumentacji związanej ze sprawowaniem przez hetmanów władzy administracyjnej nad wojskiem jest korespondencja o charakterze służbowym, którą hetmani otrzymywali w bardzo dużej liczbie od szerokiego kręgu informatorów. Korespondencja stanowiła bodaj najistotniejszy element w systemie dowodzenia i administrowania wojskiem. Z braku innych środków komunikacji, z wyłączeniem osobistych kontaktów hetmanów z podwładanymi, była ona w zasadzie jedyną formą porozumiewania się, która pozwalała im na wydawanie rozkazów, sprawowanie kontroli nad wojskiem, otrzymywanie informacji dotyczących zagrożenia zewnętrznego oraz stanu poszczególnych oddziałów.

Korespondencję przesyłaną do hetmanów można pogrupować według dwóch kryteriów. Pierwsze kryterium to nadawca listu - w tym przypadku całą

38 Tamże, sygn. IX 3/48.

39 AP w Krakowie, APd II, sygn. 83, s. 1-21, Stamlista leibkompanii regimentu pieszego buławy polnej koronnej z 1 VI 1755 r. 
korespondencję o charakterze czysto wojskowym można podzielić na listy od osób pełniących zawodową służbę wojskową i od osób cywilnych, niezwiązanych z hetmanem stosunkiem służbowym na polu wojskowości. Pierwsza grupa to urzędnicy koronni sprawujący funkcje wojskowe, wynikające z piastowanego urzędu, dowódcy poszczególnych oddziałów wojskowych podlegających władzy hetmańskiej, a w końcu zwykli żołnierze. Natomiast do drugiej grupy korespondentów można zaliczyć głównie urzędników i dygnitarzy koronnych oraz ziemskich, dostojników duchownych, wreszcie inne osoby nienależące do grup wyżej wymienionych, połączone $\mathrm{z}$ hetmanem więzami prywatnymi.

Drugie kryterium to treść korespondencji. Jak wyżej wspomniano, interesuje nas korespondencja związana z kompetencjami czysto administracyjnymi urzędu hetmańskiego, wobec tego można ją podzielić na listy o charakterze informacyjnym, których nadawcami były najczęściej osoby wojskowe pozostające $\mathrm{z}$ hetmanem w stosunku zależności służbowej oraz w drugiej kolejności osoby prywatne. Listy tego rodzaju miały bardzo często charakter raportów, sprawozdań z przygotowania i przebiegu działań wojennych, relacji o sytuacji na granicach bądź w krajach sąsiednich, w końcu zawierały informacje na temat stanu oddziałów. Inną bardzo liczną grupę listów stanowią petycje i prośby kierowane do hetmanów, zarówno od osób wojskowych, jak i cywilnych. Najczęściej były to prośby o awans, urlop, wypłacenie żołdu bądź innych należności, libertację dóbr od stancji wojskowych, wystawienie egzemptu, czyli świadectwa zwalniającego z czasowej odpowiedzialności przed urzędami sądowymi, itp. Ostatnia grupa korespondencji to listy o charakterze dyrektywnym, których wystawca był zazwyczaj panujący, ewentualnie osoba działająca na jego polecenie. Zapoznając się z licznie zachowaną korespondencją w archiwach Jana Zamoyskiego, Stanisława Koniecpolskiego, Adama Mikołaja Sieniawskiego i Jana Klemensa Branickiego, można napotkać wszystkie trzy rodzaje korespondencji.

Wśród listów o charakterze informacyjnym, których autorami byli wojskowi, można wymienić chociażby list Bartosza Ostrowieckiego z 1592 r., informujący hetmana Zamoyskiego o beznadziejnym stanie zaopatrzenia zamków w Inflantach, „że już gorzej być nie może”"40, czy rotmistrza Tomasza Dąbrowy z 1603 r., zawiadamiający o sytuacji w Inflantach i szczegółowo opisujący działania roty dowodzonej przez Dąbrowę ${ }^{41}$. Podobny charakter ma list napi-

40 AGAD, AZ, sygn. 134, list 4, Bartosz Ostrowiecki do Jana Zamoyskiego, Kiessa, 30 VII 1592 r.

41 Tamże, list 9, Tomasz Dąbrowa, rotmistrz, do Jana Zamoyskiego, Felin, 23 VI $1603 \mathrm{r}$. 
sany do Stanisława Koniecpolskiego przez rotmistrza Andrzeja Natkowskiego ${ }^{42}$ czy raport od hetmana polnego koronnego Mikołaja Potockiego ${ }^{43}$. Archiwa Sieniawskiego i Jana Klemensa Branickiego są przepełnione tego rodzaju listami. Ich charakterystycznym przykładem jest korespondencja między hetmanami. W archiwum Jana Zamoyskiego zachowały się listy hetmana polnego koronnego Stanisława Żółkiewskiego kierowane do ówczesnego hetmana i kanclerza wielkiego koronnego ${ }^{44}$, a w archiwum Mikołaja Sieniawskiego listy od Hieronima Augustyna Lubomirskiego ${ }^{45}$ i Stanisława Mateusza Rzewuskiego ${ }^{46}$. W archiwum Jana Klemensa Branickiego znajduje się zaś korespondencja od Józefa Potockiego, hetmana wielkiego koronnego ${ }^{47}$, natomiast po nominacji Branickiego na hetmaństwo wielkie - od Wacława Rzewuskiego, który zajął jego miejsce na urzędzie hetmana polnego ${ }^{48}$. W tym miejscu można również wymienić listy królów jako zwierzchników hetmanów, bardzo często zawierające informacje związane ze sprawami wojskowymi ${ }^{49}$.

Wśród listów od osób cywilnych występuje bardzo duża liczba pism, których nadawcami są urzędnicy koronni i ziemscy, bezpośrednio zainteresowani sprawami sił zbrojnych. Można wymienić chociażby korespondencję od Janusza Ostrogskiego, kasztelana krakowskiego, który w liście pisanym 27 września 1595 r. informował Zamoyskiego o sytuacji na Ukrainie i zagrożeniu ze strony Tatarów. W podobnym tonie jest utrzymany list od wojewody bracławskiego Janusza Zbaraskiego do hetmana polnego koronnego Stanisława Żółkiewskiego ${ }^{50}$ czy od chorążego bracławskiego Stefana Chmielewskiego do Stanisława

42 Tamże, sygn. 446, s. 77, rotmistrz Andrzej Natkowski do Jana Zamoyskiego, Helzbark, 5 IX 1628 r.

43 Tamże, sygn. 2864, s. 101-104, Mikołaj Potocki, hetman polny koronny, do Stanisława Koniecpolskiego, Borek, 9 XI 1645 r.

44 Tamże, sygn. 273.

$45 \mathrm{BCz}$, sygn. $2518 \mathrm{IV}$, s. 337-498.

46 Tamże, sygn. 5939.

47 AGAD, ARo, Korespondencja, pudło XVII/4.

48 Tamże, pudło XIX/27.

$49 \mathrm{Na}$ przykład korespondencja do Jana Zamoyskiego od Stefana Batorego i Zygmunta III Wazy, zob. AGAD, AZ, sygn. 141, 142; korespondencja Zygmunta III i Władysława IV do Stanisława Koniecpolskiego, tamże, sygn. 446; tamże, sygn. 2864, sygn. 3048; AGAD, Archiwum Publiczne Potockich 1551-1879 (dalej: APP), sygn. 7, t. 2; Ossol., sygn. 1925/II.

50 AGAD, AZ, sygn. 3036, s. 329, list wojewody bracławskiego Janusza Zbaraskiego, Krzemieniec, 24 II 1593 r. 
Koniecpolskiego ${ }^{51}$. Generalnie wśród grupy nadawców korespondencji tego rodzaju dominują urzędnicy ziem pogranicznych, ewentualnie ci, których dobra były narażone na szczególne zniszczenia $\mathrm{w}$ trakcie działań wojennych. Zresztą właśnie przedstawiciele rodzin osiadłych na kresach dowodzili często zaciężnymi rotami. Ponadto zwyczajowo niektórzy urzędnicy ziemscy, jak np. starostowie, kasztelanowie i wojewodowie, pełnili również w czasie zagrożenia funkcje wojskowe, stąd w archiwach hetmańskich tak liczna od nich korespondencja.

Znaczną grupę wśród listów kierowanych do hetmanów koronnych, jako generalnych dowódców wojska, stanowią różnego rodzaju petycje i prośby dotyczące albo spraw wewnętrznych wojska, albo też spraw odnoszących się i do wojska, i do osób cywilnych jednocześnie, przy czym autorami listów pierwszego rodzaju byli wojskowi, natomiast drugiego rodzaju najczęściej osoby prywatne. W pierwszym przypadku prośby i petycje wojskowych dotyczyły spraw związanych z wynagrodzeniem za pełnioną służbę. Taki charakter ma pismo grupy rotmistrzów i towarzyszy, którzy prosili hetmana Zamoyskiego o nagrodę dla niejakiego Piwka, czy Marka Sobieskiego z 1601 r., który zalecał Zamoyskiemu wzięcie w łaskę Farnhaltsa, niższego dowódcę wybrańców pruskich ${ }^{52}$. Inną nieco prośbę wystosował do hetmana i kanclerza koronnego Jakub Potocki - w liście z 23 czerwca 1598 r. w związku z organizacją nowego zaciągu pisał on m.in.: „A mnie z zwykłej łaski swej przy stu koni zachować będziesz raczył” ${ }^{33}$. Nie trzeba chyba wyjaśniać prośby Potockiego, który w przypadku otrzymania listu zaciężnego na rotę 50-konną mógł liczyć na dużo mniejsze dochody.

Inny charakter mają petycje osób prywatnych. Najczęściej są one związane z nadużyciami, jakich dopuszczały się wojska podlegające władzy hetmana. Tak na przykład Zygmunt Herburt w liście do Jana Zamoyskiego, datowanym 19 maja 1603 r., napisał: „skarżę się przy tem WM memu Mści Panu, że rota JMP Leśniowolskiego poczyniła mi wielkie szkody w dzierżawie Mościskiej, idąc do Medyki na stanowisko. Teraz zaś znowu rota Je.M.P. Wacława Zamoyskiego posłała do tychże Mościsk dla rozpisowania gospod, uniżenie proszę WM Mści Pana racz listy swemi obronić tej chudoby mojej, wszak i służyłem też pierwej i jeszczem gotów dla Pana Boga służyć" 54 . Podobny charakter ma list wojewody pomorskiego Samuela Konarskiego, który pro-

51 Tamże, sygn. 446, s. 41-42, list Stefana Chmielewskiego, chorążego bracławskiego, z Nowego Międzyboża, 24 XI 1624 r.

52 Tamże, sygn. 134, 245, k. 25.

53 Tamże, sygn. 228, k. 38.

54 Tamże, sygn. 190, k. 84. 
sił Stanisława Koniecpolskiego o pomoc w związku z najazdem na jego dobra niepłatnego wojska ${ }^{55}$.

Kolejną grupą spraw bardzo często poruszaną w korespondencji do hetmanów były listy z prośbami o protekcję. Zazwyczaj hetmańskie poparcie miało zaowocować awansem proszącego, ewentualnie osoby drugiej. Władysław IV prosił Koniecpolskiego o umożliwienie służby w wojsku jego dworzaninowi Pawłowi Janczemu ${ }^{56}$, hetman polny Wacław Rzewuski zabiegał u Jana K. Branickiego o awans dla stolnika płockiego Jeżewskiego ${ }^{57}$, a hetman polny litewski Michał Massalski do tegoż Branickiego zwracał się o protekcję dla towarzysza husarskiego Ochotnickiego ${ }^{58}$.

Ostatnią grupę korespondencji związaną z administracyjną władzą hetmanów stanowią listy o charakterze dyrektywnym, pisane do nich przez króla, ewentualnie osoby przez monarchę upoważnione, a także listy-rozkazy kierowane przez hetmanów wielkich do polnych. Takich listów nie ma jednak zbyt wiele, większość pism króla Zygmunta III i Władysława IV do Zamoyskiego i Koniecpolskiego zawiera raczej różnego rodzaju prośby niż rozkazy. Jednakże można spotkać listy będące jasno sformułowanymi poleceniami, np. list z 26 maja 1595 r., w którym król Zygmunt III polecał Zamoyskiemu, aby wspomógł starostę kamienieckiego w zdobyciu Chocimia, list z 25 maja 1599 r., w którym nakazywał hetmanowi koronnemu zwalczanie „kup swawolnych” na mocy konstytucji z 1593 r., czy w końcu list z 11 grudnia 1601 r., w którym polecał mu przydzielić do którejś z rot kilkunastokonny poczet starosty chelmetskiego Piotra Noubarda ${ }^{59}$. Dosyć nietypowy rozkaz otrzymał natomiast Stanisław Koniecpolski od Władysława IV. Miał bowiem uwolnić starościankę halicką, którą porwał starosta bracławski Kalinowski przy pomocy żołnierzy z roty kwarcianej ${ }^{60}$.

Innego rodzaju archiwaliami, znajdującymi się w archiwach hetmańskich, są dokumenty odzwierciedlające przebieg działań wojennych. Hetmani jako naczelni wodzowie byli odbiorcami wszelkiej dokumentacji dotyczącej spraw

55 Tamże, sygn. 446, s. 29, list woj. pomorskiego Samuela Konarskiego z Kiszewa, 18 XI 1626 r.

56 Tamże, sygn. 3048, s. 537-538, list króla Władysława IV z Warszawy, 26 VII $1643 \mathrm{r}$.

57 AGAD, ARo, Korespondencja, pudło XIX/27, s. 22-23, list Wacława Rzewuskiego z 15 I 1572 r.

58 Tamże, pudło XIII/48, list Michała Massalskiego, hetmana wlk. litewskiego, z 1766 r.

59 AGAD, AZ, sygn. 142, listy 14, 35, 48.

60 Ossol., sygn. 1925/II. 
wojskowych, zarówno na szczeblu taktycznym, jak i operacyjnym. Przykładem może być regestr artylerii, jaką wojska moskiewskie miały ewakuować z Inflant po podpisaniu traktatu w Jamie Zapolskim w 1582 r. $^{61}$ Akta tego rodzaju napływały do głównej siedziby Zamoyskiego, to znaczy do Zamościa, jak również był on ich odbiorcą w innych miejscach. Najczęściej chyba trafiały one do hetmańskiego archiwum w trakcie wypraw wojennych. Wiadomo, że podczas wyprawy pskowskiej w 1581 r. Zamoyski otrzymywał w obozie zestawienia liczbowe pocztów i rot od poszczególnych rotmistrzów ${ }^{62}$. Podobnie jak w archiwum Jana Zamoyskiego, dużo dokumentacji o charakterze spisów, które powstały okazjonalnie w wyniku prowadzenia działań wojennych, zachowało się w archiwum Adama Sieniawskiego. Taki charakter mają „konnotacja aresztantów szwedzkich”, „specyfikacja zabitych i w niewolę wziętych” czy zestawienie jeńców, stronników Leszczyńskiego wziętych do niewoli w 1712 r. $^{63}$

W archiwum podhoreckim Rzewuskich, z której to rodziny w XVIII w. aż trzech przedstawicieli sprawowało urząd hetmana koronnego, zachowało się sporo oryginalnych ordynansów (aktów o charakterze rozkazów), uniwersałów (aktów o charakterze informacyjnym), a także ich kopii wydawanych przez osoby pełniące różne funkcje wojskowe, dotyczących generalnie oddziałów bezpośrednio podlegających hetmanom. Wśród najczęstszych autorów tych akt występują: generał lejtnant wojska koronnego Antoni Benedykt Lubomirski, pełniący funkcję dowódcy regimentu infanterii buławy polnej koronnej, kiedy urząd hetmana polnego piastował Wacław Rzewuski, generał artylerii kor. Alojzy Fryderyk Brühl oraz Komisja Wojskowa, kiedy hetmanem polnym koronnym był Seweryn Rzewuski ${ }^{64}$. W przypadku oryginalnych ordynansów, których odbiorcami były osoby służące w regimentach hetmańskich, trafiały one do archiwum hetmańskiego nie zawsze w komplecie. Można przypuszczać, że dostawały się tam sporadycznie, tak jak choćby ordynans wydany przez wspomnianego wyżej Antoniego Lubomirskiego dla kapitana Andrzeja Prołowskiego, zarządzającego kasą regimentową ${ }^{65}$. W myśl ordynansu Prołowski otrzymał polecenie stawienia się w określonym czasie z rachunkami kasy w Podhorcach, głównej siedzibie hetmana Rzewuskiego. Najprawdopodobniej, przyjeżdżając do Podhorzec, powołał się on na ordynans Lubomirskiego i w ten sposób rozkaz ten trafił do archiwum hetmańskiego. Natomiast nieco

61 AGAD, AZ, sygn. 3112, k. 23-31.

62 J. Piotrowski, Dziennik wyprawy Stefana Batorego pod Psków, wyd. A. Czuczyński, Kraków 1894, s. 187.

63 BCz, sygn. 2634 IV; sygn. 2635 IV, t. 2.

64 AP w Krakowie, APhAP, sygn. V 1/8a, 11b, 16, IX 3/100-102, 108-110.

65 Tamże, sygn. V 1/8a. 
inaczej przedstawia się sprawa z kopiami ordynansów. Komendy poszczególnych oddziałów podlegających bezpośrednio władzy hetmanów były zobowiązane do przesyłania do kancelarii hetmańskiej okresowo kopii otrzymanych ordynansów. Tego rodzaju zestawienie ordynansów, otrzymanych od generała majora Arnolda Byszewskiego, dowódcy dywizji małopolskiej, przesłał do kancelarii hetmańskiej podp. Bałła. Każdą kopię zaopatrywano dla większej wiarygodności w adnotację „concordat cum originali” z podpisem osoby ją sporządzającej ${ }^{66}$. Bardzo ciekawym przykładem zestawienia rozkazów wydawanych przez Seweryna Rzewuskiego w 1793 r. są tzw. excerpty ordynansów. Były one przygotowywane $\mathrm{w}$ formie tabelarycznej i zawierały następujące rubryki: numer porządkowy ordynansu, data wysłania, data odebrania, treść, termin i sposób wykonania rozkazu ${ }^{67}$.

Oczywiście, w archiwach hetmanów zachowały się także ordynanse, których bezpośrednimi odbiorcami byli oni sami. Najczęściej dotyczyło to hetmanów polnych, otrzymujących rozkazy od hetmanów wielkich. W archiwum Rzewuskich zachowały się takie ordynanse dla Wacława Rzewuskiego wydane przez Jana Klemensa Branickiego w 1752 r. oraz dla Seweryna Rzewuskiego wydane przez Konfederację Generalną Obojga Narodów w 1793 r. ${ }^{68}$ Swego rodzaju ordynansami były również wspomniane wyżej listy królewskie, zawierające dyrektywy dla hetmanów. Trzeba też dodać, że w archiwach hetmańskich zachowały się także oryginalne ordynanse oraz ich kopie wydawane przez hetmanów różnym osobom, a więc teoretycznie niemające swojego miejsca (w przypadku oryginałów) w ich archiwach. W praktyce jednak okazywało się, że ordynanse wychodzące z kancelarii hetmańskiej bardzo często wracały do miejsca ich wystawienia. Wydaje się, że działo się tak przede wszystkim dlatego, że ordynanse bez względu na wystawcę miały trafiać ostatecznie do bezpośredniego zwierzchnika oddziałów, dla których były wystawione. Po drugie, mogły znaleźć się w archiwum hetmańskim już po śmierci ich wystawcy w związku z kolekcjonowaniem pamiątek rodzinnych. W końcu ordynanse przygotowane w kancelarii hetmańskiej do ekspedycji z powodu zmiany sytuacji mogły nigdy

66 Tamże, sygn. VI 1/123.

67 Na przykład „Excerpt ordynansów doszłych od dnia 15 stycznia do dnia 15 lutego 1973 r. z wyrażeniem w jaki sposób, który jest uskuteczniony”, sporządzony w Grodzisku 24 II 1793 r. przez gen. lej. Byszewskiego, czy „Excerpt odebranych i uskutecznionych ordynansów, zaleceń w responsach od Jw. Rzewuskiego h.p.k. od dnia 14.03. do dnia 7 kwietnia do dywizji małopolskiej i garnizonu warszawskiego wydanych", sporządzony przez gen. lej. Piotra Ożarowskiego, AP w Krakowie, APhAP, sygn. V 2/27, X 1/12.

68 Tamże, sygn. V 1/6a, 6c, VIII 4/24-26. 
jej nie opuścić i trafiały do archiwum ${ }^{69}$. W archiwum Jana Zamoyskiego zachowały się na przykład cztery jednobrzmiące egzemplarze rozkazu z podpisem hetmana wystawione w Rydze w marcu 1582 r., w których nakazywał on karność i przestrzeganie prawa przez wojsko ${ }^{70}$. Te ordynanse nigdy nie wyszły z kancelarii hetmańskiej, o czym świadczą puste pola na wpisanie liczby jezdnych, nazwiska rotmistrza, daty dziennej ich wystawienia i miejsca postoju roty, do której miały być skierowane. Tutaj znajdują się również uniwersały hetmańskie, jeden bez podpisu i pieczęci, być może kopia, datowany 20 lutego 1590 r. w Stojano$w_{i e}^{71}$, drugi z podpisem hetmana, ale bez jego pieczęci, datowany w Wolmierzu 23 stycznia $1601 \mathrm{r}^{72}$

Oczywiście, w archiwach hetmanów znajduje się dużo więcej archiwaliów, które teoretycznie powinny znajdować się w zasobach innych archiwów. Na przykład w archiwum Zamoyskiego jest to oryginał listu egzemptu wystawionego 5 grudnia 1600 r. w Kamieńcu dla starosty żmudzkiego Jana Karola Chodkiewicza i jego brata Aleksandra ${ }^{73}$ czy list z 24 marca 1597 r. nakazujący rotmistrzowi Janowi Potulickiemu wraz z rotą stawić się przed hetmanem ${ }^{74}$.

\section{DOKUMENTACJA FINANSOWA}

Materiały archiwalne o charakterze finansowym stanowiły poważny fragment zasobów archiwów hetmańskich. Generalnie akta tego rodzaju zaczęły pojawiać się w nich praktycznie od początku funkcjonowania hetmaństwa, chociaż ich ilość oraz charakter ulegały wyraźnym przemianom. Wynikało to ze zmieniających się prerogatyw hetmanów koronnych, których władza związana z finansowaniem, a dokładniej rzecz ujmując - nadzorem nad rozdziałem funduszy na wojsko koronne, została usankcjonowana prawnie w XVII w., osiągając nienaturalne wręcz rozmiary na przełomie XVII i XVIII w., a ulegając radykalnemu ograniczeniu w latach 1716-1717.

Archiwalia o charakterze finansowym występujące w archiwach hetmańskich można zasadniczo podzielić na trzy grupy. Pierwszą grupę stanowi doku-

69 Wśród oryginalnych ordynansów, wystawionych przez hetmanów, które zachowały się w ich archiwach, można wymienić ordynanse Wacława Rzewuskiego i Seweryna Rzewuskiego; tamże, sygn. IV 1/46a, 54a, V 1/30-31, 34-36, 38-39, 176.

70 AGAD, AZ, sygn. 640, list 4.

71 Tamże, list 12.

72 Tamże, list 23.

73 Tamże, list 39.

74 Tamże, list 31. 
mentacja bardziej osobista, związana z utrzymaniem finansowym oddziałów bezpośrednio podlegających hetmanom (tak zwane regimenty i chorągwie hetmańskie). Do drugiej grupy należy zaliczyć akta związane z zabezpieczeniem uposażenia urzędu hetmańskiego, natomiast na grupę trzecią składa się dokumentacja archiwalna powstała w wyniku sprawowania przez hetmanów funkcji finansowych w stosunku do wojsk koronnych. Niestety, podobnie jak w przypadku akt administracyjnych te spostrzeżenia będą oparte głównie na archiwach hetmanów osiemnastowiecznych, z tym że akurat początek XVIII w. stanowił okres największego rozkwitu skarbowej władzy hetmanów, w związku z czym dzięki doskonale zachowanemu archiwum Adama Mikołaja Sieniawskiego można poznać ten rodzaj dokumentacji bardzo szczegółowo. W tym miejscu zostaną omówione archiwalia ostatniej grupy, dwie pierwsze natomiast zostaną scharakteryzowane w kolejnych częściach artykułu, dotyczących dokumentacji osobistej hetmanów oraz ich oddziałów przybocznych.

W archiwum Jana Zamoyskiego z dokumentacji finansowej występują wspomniane już wyżej, przy okazji omówienia dokumentacji administracyjno-wojskowej, różnego rodzaju spisy oddziałów, z uwzględnieniem informacji na temat ich uposażenia. Najprawdopodobniej takie archiwalia występowały w archiwach innych hetmanów koronnych do połowy XVII w., to jest do czasu, kiedy hetman wielki otrzymał znaczne uprawnienia w zakresie utrzymywania wojska, w tym między innymi prawo rozdawania asygnacji i rozdziału hiberny. Dotychczas te kompetencje należały do podskarbiego koronnego. Hetmanowie koronni bardzo często zasiadali w pracach dwóch komisji (skarbowej i hibernowej), które zajmowały się utrzymywaniem wojska koronnego, stąd w ich archiwach pojawiła się dokumentacja odzwierciedlająca tę działalność. Archiwalia tego rodzaju były na pewno zgromadzone w archiwum Stanisława Jana Jabłonowskiego ${ }^{75}$.

Wydaje się jednak, że dokumentacja finansowa najliczniej występowała w archiwum Adama Mikołaja Sieniawskiego. Odgrywała w nim niebagatelną rolę, o czym świadczy nie tylko jej znaczenie merytoryczne, ale również masowy charakter. W żadnym innym hetmańskim archiwum nie była ona chyba reprezentowana w takiej liczbie i różnorodności. Nieprzypadkowo właśnie ta dokumentacja została dokładnie zarejestrowana w sumariuszu archiwum hetmańskiego Sieniawskiego ${ }^{76}$. Zawiera on opis kilku rodzajów tego typu dokumentacji, którą podzielono na następujące grupy: 1. akta komisji hibernowych,

75 BCz, sygn. $2598 \mathrm{IV}$.

76 Tamże, sygn. 2470 IV. 
2. akta likwidacji wojsk koronnych, 3. akta dyspozycji i dystrybuty hibern, 4. akta związane z zaopatrzeniem regimentów A. M. Sieniawskiego.

W przypadku archiwaliów odzwierciedlających działalność komisji hibernowych sumariusz ujmuje 11 pozycji, na które składały się wypisy z ksiąg komisji hibernowej lwowskiej, powstałe w latach $1685-1714^{77}$. Jest to o tyle ważne, że w tym czasie nastąpił bardzo duży wzrost kompetencji finansowych Adama Sieniawskiego. W początkowym okresie wojny północnej zawieszono bowiem działalność komisji hibernowej, a pełnomocnictwa do wykonywania jej obowiązków powierzono ówczesnemu hetmanowi wielkiemu.

Organicznie związane ze skarbowymi kompetencjami hetmanów są dyspozycje dotyczące dystrybuty hiberny, czyli rozdział środków finansowych na poszczególne oddziały wojska koronnego, czynione w okresie aktywności komisji hibernowej z lat $1705-1715^{78}$. W tym miejscu należy również wspomnieć o zestawieniach taryf hibernowych, na podstawie których wybierano z dóbr królewskich hibernę w latach 1710-1712 $2^{79}$. W archiwum Sieniawskiego zachowała się także księga będąca zestawieniem kwarty i hiberny wydawanej według kwitów Sieniawskiego na potrzeby artylerii koronnej w latach $1705-1707^{80}$. Można podejrzewać, że podobny charakter miał niezachowany do dzisiaj, ale ujęty w wyżej wzmiankowanym sumariuszu „Manuał kwarty dwojej sympli z dóbr j.k.m. i rzpltej na rok 1709 " 81 .

Wśród archiwaliów finansowych $\mathrm{z}$ archiwum hetmańskiego Sieniawskiego, dotyczących generalnie całego wojska koronnego, należy wspomnieć również o innego rodzaju dokumentacji niezwiązanej z działalnością komisji skarbowych. Można wymienić chociażby zestawienie kosztów utrzymania wojska pozostającego pod dowództwem Sieniawskiego w latach 1708-1709 z kasy cara Piotra Wielkiego ${ }^{82}$.

Do archiwaliów o charakterze finansowym wypada też zaliczyć tak zwane komputy wojsk, to znaczy zestawienia liczebne oddziałów wojskowych zaciągniętych legalnie na potrzeby Rzeczypospolitej, na podstawie których dokonywano rozliczeń finansowych związanych z ich utrzymaniem. Takie zestawienia stanowiły bardzo ważną część dokumentacji hetmanów wielkich, którzy odpowiadali za zgodność stanu realnego wojsk koronnych ze stanem uchwalonym w kompucie. W archiwum Sieniawskiego sporządzono nawet w 1724 r. odręb-

77 Tamże, sygn. 2557 IV; sygn. 2558 IV.

78 Tamże, sygn. 2700 IV; sygn. 2671/1 IV-2671/9 IV.

79 Tamże, sygn. 2674/2-3; sygn. 2591 IV.

80 Tamże, sygn. 2590 IV.

81 Tamże, sygn. 2470 IV, s. 8.

82 Tamże, sygn. 2607/III. 
ną księgę, zawierającą zestawienia komputów wojska koronnego w okresie piastowania urzędów hetmańskich przez Adama Mikołaja ${ }^{83}$. Znajdują się tam między innymi akta limitacji komisji hibernowych, postulaty (tzw. punkta) wojska i szlachty dotyczące poboru oraz rozdziału podatków przeznaczonych na wojsko, komputy wojska czy w końcu dyspozycje oddziałów wojskowych na leże.

Trzeba wreszcie wspomnieć i o tym, że również korespondencja po części odnosiła się do spraw związanych z utrzymaniem wojska. W listach poruszano zazwyczaj problem jego finansowego zaopatrzenia. Bardzo często ten wątek występował w korespondencji od królów i osób z kręgów decyzyjnych ${ }^{84}$. Żołnierze natomiast zwracali się do hetmanów zwykle z prośbami o wypłacenie im zaległych należności.

\section{DOKUMENTACJA SĄDOWNICZA}

Omawiając sądownicze uprawnienia hetmanów, trzeba zwrócić uwagę na fakt ich rozległej władzy jurysdykcyjnej, sprawowanej głównie podczas prowadzenia działań wojennych. Hetmanowi przysługiwało wtedy nawet prawo karania śmiercią. Przeglądając zasoby archiwów hetmańskich, można zauważyć, że akta związane ze sprawowaniem przez nich władzy sądowniczej występują w znikomej liczbie. Najczęściej są to sprawozdania sądów wojennych (tzw. krygsrechtów), powoływanych (wysadzanych) przez hetmanów na mocy ordynansów w celu przeprowadzenia śledztwa (inkwizycji), a następnie wydania wyroku (dekretu), który był również przesyłany do kancelarii hetmańskiej $\mathrm{w}$ celu zaaprobowania go przez hetmana ${ }^{85}$. Ponadto z jurysdykcją hetmańską wiążą się też apelacje od wyroków, kierowane przez skazanych do hetmanów. Występują one jednak w bardzo niewielkiej liczbie. Tego rodzaju dokumentacja zachowała się między innymi w archiwum pozostałym po Adamie Mikołaju Sieniawskim ${ }^{86}$.

W archiwach hetmańskich zachowały się także akta wychodzące z kancelarii hetmańskiej, dotyczące sprawowania władzy sądowniczej przez hetmanów.

\section{Tamże, sygn. 2589 IV.}

${ }^{84} \mathrm{Na}$ przykład listy Zygmunta III do Jana Zamoyskiego, zob. AGAD, AZ, sygn. 142, listy $33,42,49,52$.

$85 \mathrm{~W}$ archiwum J. K. Branickiego zachował się sumariusz akt przesłanych hetmanowi w 1761 r. przez generała lejtnanta Lubomirskiego, wojewodę lubelskiego, wśród których znajdował się między innymi „Dekret na Muszkietera Szultza; jeden po polsku; drugi po niemiecku [...] do approbaty JW JEMci Pana Hetmana W. Koronnego", AGAD, ARo, Militaria, pudło 4.

${ }^{86}$ BCz, sygn. 2633/IV; sygn. 2635/IV, t. 2, s. 157-158. 
W pierwszej kolejności są to oryginały i kopie ordynansów hetmańskich, polecających przeprowadzenie śledztwa oraz wydanie wyroku w związku z popełnieniem wykroczeń regulaminowych przez osoby podlegające władzy hetmana. W archiwum podhoreckim Rzewuskich zachował się ordynans Wacława Rzewuskiego, w którym nakazał on pułkownikowi Wieniawskiemu, dowodzącemu regimentem pieszym buławy polnej, żeby wyznaczył grupę oficerów do przeprowadzenia śledztwa, a następnie zorganizował sąd wojenny, który wydałby wyrok ${ }^{87}$.

Oprócz wyżej wymienionych dokumentów dotyczących jurysdykcji hetmańskiej dosyć ciekawy materiał, podobnej proweniencji tematycznej, zachował się w Archiwum Roskim, gdzie znalazły się akta Jana Klemensa Branickiego oraz Józefa Potockiego. Obejmują one między innymi tabele, projekty i ekscerpty związane ze składem "generał krygsrechtu radomskiego”, to znaczy generalnego sądu wojskowego, który działał przy Trybunale Skarbowym w Radomiu, oraz jego dekrety, a także pozwy, inkwizycje oraz dekrety i objaśnienia do spraw omówionych powyżej ${ }^{88}$. Z okresu sprawowania przez Jana Klemensa Branickiego urzędu hetmana wielkiego koronnego w latach 1751-1752 zachowało się w jego archiwum bardzo dużo akt związanych z jego uprawnieniami sądowniczymi. Występują tutaj akta działalności sądów wojskowych praktycznie wszystkich regimentów podlegających władzy hetmana. Na przykład w dokumentacji dotyczącej regimentu pieszego królewicza i Rzeczypospolitej znalazły się akta konfliktu między komendantem wymienionego regimentu generałem majorem Goltzem a jego obersterlejtnantem Sułkowskim. Są to między innymi memoriały pisane w tej sprawie przez Goltza do Branickiego ${ }^{89}$. W aktach regimentu pieszego łanowego zachowały się natomiast dwie oblaty ugody zawartej między oficerami a regimentem ${ }^{90}$.

$\mathrm{Na}$ temat działalności sądowniczej hetmanów w połowie XVIII w. dużo mówi treść jednego z rękopisów z archiwum Rzewuskich. Jest to swego rodzaju kopiariusz zawierający wzory różnych pism wychodzących z kancelarii hetmańskiej. Między innymi znajdują się tutaj przykłady kilku rodzajów aktów wystawianych przez hetmanów w zakresie ich władzy jurysdykcyjnej: kontumacje, pozwy hetmańske oraz dekrety „trąby” na wyrzuconych z armii żołnierzy.

Warto zastanowić się, dlaczego w archiwach hetmanów zachowało się tak niewiele dokumentacji sądownictwa hetmańskiego. Odpowiedź jest prosta.

\footnotetext{
87 AP w Krakowie, APd II, sygn. 111, s. 29-30.

88 AGAD, ARo, Militaria, pudło 3, plik 5, wiązki 1-3.

89 Tamże, pudło 7, plik 3.

90 Tamże, pudło 8, plik 7.
} 
Hetmani rzadko zajmowali się osobiście sądzeniem. Bardzo wcześnie przelali swoje obowiązki sądownicze na kolegialne ciała, sądy wojskowe, którym mogli przewodniczyć, choć czynili to chyba tylko w wyjątkowych sytuacjach. W myśl instrukcji o sądownictwie wojskowym sądy hetmańskie, a więc takie, którym osobiście przewodniczył hetman, rozpatrywały sprawy o zdradę stanu (przez to pojęcie rozumiano działania wymierzone przeciwko królowi oraz współpracę z wrogami Rzeczypospolitej) oraz znieważenie słowem lub czynem hetmana, hetmańskiego gubernatora oraz generalnego oficera. W obecności hetmana mieli być sądzeni wyżsi oficerowie oraz polska szlachta pozostająca w relacjach zależności wojskowej od hetmana91.

\section{DOKUMENTACJA DYPLOMATYCZNA}

Działalność dyplomatyczna hetmanów odzwierciedliła się w ich archiwach właściwie tylko w postaci korespondencji. Konieczność dobrej orientacji w stosunkach międzypaństwowych oraz sytuacji wewnętrznej państw ościennych Rzeczypospolitej zaowocowała w archiwach hetmańskich różnorodnością listów nadsyłanych do hetmanów. Tę korespondencję można pogrupować w zależności od nadawcy. Pierwszy rodzaj korespondencji związanej z uprawnieniami dyplomatycznymi hetmanów to listy od panujących i ich najwyższych urzędników, w tym ambasadorów i posłów państw obcych w Rzeczypospolitej; drugi rodzaj to listy od niższych urzędników państw obcych, trzecia grupa to listy od posłów i rezydentów Rzeczypospolitej oraz hetmańskich. Zwyczaj korespondowania przez hetmanów z obcymi monarchami i ich przedstawicielami pojawił się na pewno już w pierwszej połowie XVI w. Na dosyć szeroką skalę taką działalność prowadził Jan Tarnowski. Czasy Jana Zamoyskiego przyniosły rozkwit dyplomatycznej aktywności hetmaństwa, na co bez wątpienia miało wpływ jednoczesne sprawowanie kanclerstwa i hetmaństwa przez Zamoyskiego przez okres 24 lat (1581-1605). Od tej pory hetmani zwyczajowo utrzymywali kontakty zagraniczne, nawet po 1717 r., kiedy to oficjalnie zabroniono im tej działalności. Trzeba jednak wspomnieć, że korespondowanie z obcymi monarchami bądź też ich przedstawicielami nie było monopolem hetmanów. Każdy możnowładca, magnat o ambicjach politycznych, mający odpowiednie środki materialne, stawiał sobie za punkt honoru nawiązanie najmniejszego chociażby kontaktu z ośrod-

91 AP w Krakowie, APd II, sygn. 154, s. 62-64. 
kami władzy za granicą. To zjawisko szczególnie nasiliło się w drugiej połowie XVII i w XVIII w.

Dokumentacja dyplomatyczna zachowana w archiwach hetmańskich ma dwojaki charakter, w zależności od stosunków z danym państwem. Jeżeli między Rzecząpospolitą a jej sąsiadem panowały dobrosąsiedzkie relacje, to w korespondencji przeważały listy grzecznościowe, wyjaśniające wydarzenia wewnętrzne oraz opisujące sytuację międzynarodową. Jeżeli jednak stosunki międzypaństwowe psuły się, w korespondencji pojawiały się wątki roszczeniowe, zarzucające drugiej stronie brak dobrej woli w rozwiązywaniu spornych spraw. Wówczas posłowie Rzeczypospolitej informowali hetmanów o położeniu militarnym przeciwnika, ruchach jego wojsk, naczelnym dowództwie, nastrojach społecznych itp.

Wśród listów panujących do hetmanów koronnych należy wymienić przede wszystkim pisma władców państw graniczących z Rzecząpospolitą: Austrii, Mołdawii, Prus, Rosji, Turcji, Wołoszczyzny i Szwecji. Można przypuszczać, że wymiana listów nasilała się w okresie wzmożonej międzynarodowej aktywności politycznej, na przykład wojen polsko-szwedzko-rosyjskich o Inflanty, wojen Rzeczypospolitej z Kozakami i Turkami. W archiwum Stanisława Żółkiewskiego zachował się list od Jeremiego Mohyły ${ }^{92}$, w archiwum hetmańskim Stanisława Koniecpolskiego zaś między innymi list od cesarza Ferdynanda $\mathrm{II}^{93}$, od Wasyla, wojewody i hospodara mołdawskiego (w sprawie kupców) ${ }^{94}$, czy asekuracja wojewody wołoskiego Mojżesza Mohyły, który zobowiązał się na jej mocy do zapłaty 1000 czerwonych złotych, 100 wołów i 30 półkowków wina w zamian za pomoc w objęciu tronu mołdawskiego ${ }^{95}$. Do Jana Klemensa Branickiego pisał między innymi król pruski Fryderyk II $^{96}$. Wśród listów od urzędników obcych państw można wymienić list gubernatora Ingrii Ottona Velingka do Stanisława Jabłonowskiego ${ }^{97}$, listy kanclerza rosyjskiego Woroncowa do Jana K. Branickiego z lat $1760-1761^{98}$ czy też do tegoż list Abdi Sereskier-Paszy ${ }^{99}$.

92 AGAD, AZ, sygn. 3028, k. 180, list od Jeremiego Mohyły, Romanów, 10 XI 1599 r.

93 Ossol., sygn. 1905/II, k. 6, list cesarza Ferdynanda II, Wiedeń, 6 I 1629 r.

94 Tamże, sygn. 2576/II, k. 36, list Wasyla, wojewody i hospodara mołdawskiego, Jassy, 22 VII 1639 r.

95 Tamże, sygn. 1905/II, k. 45, list Mojżesza Mohyły, Paniów, 30 IX 1634 r.

96 AGAD, Zbiory ARo, Kancelaria hetmańska, sygn. 982-993, listy Fryderyka II króla pruskiego z lat 1752-1755.

97 AGAD, AZ, sygn. 3031, k. 149-150, list Ottona Velingka, gubernatora Ingrii, Ryga, 30 VII 1700 r.

98 AGAD, Zbiory ARo, Kancelaria hetmańska, sygn. 2773.

99 Tamże, sygn. 15, list Abdi Seraskier-Paszy, Chocim, 11 VII 1767 r. 


\section{DOKUMENTACJA ODDZIAŁów HETMAŃSKICH}

W zasobach archiwów hetmańskich dosyć wyraźnie wyodrębnia się dokumentacja archiwalna związana z oddziałami stanowiącymi przyboczne wojsko hetmanów. Wraz z nominacją na urząd hetmański, hetmana wielkiego bądź polnego, nowo mianowany hetman otrzymywał automatycznie pod swoje bezpośrednie dowództwo chorągwie i regimenty, nazywane oddziałami buławy polnej bądź wielkiej. Hetmani stawali się nie tylko naczelnymi dowódcami wojska, ale również bezpośrednimi przełożonymi służących w nim żołnierzy, ich szefami. W związku z tym w archiwach hetmańskich zachowały się archiwalia odzwierciedlające tę właśnie zależność. W archiwum Rzewuskich znajduje się się bardzo dużo archiwaliów dotyczących funkcjonowania regimentów obu buław w okresie sprawowania hetmaństwa wielkiego i polnego przez Wacława i Seweryna Rzewuskich. Podstawowym rodzajem dokumentacji są tutaj oczywiście różnego rodzaju raporty, omówione powyżej, z tą różnicą, że trafiały one do hetmanów z większą systematycznością.

Wśród akt o charakterze finansowym związanych z płacami oraz utrzymaniem oddziałów hetmańskich występuje szereg ksiąg rachunkowych. Na przykład księga rachunkowa regimentu pieszego buławy polnej koronnej, obejmująca finanse za lata 1754-1764, zawiera oprócz zestawień wydatków również kopie listów pisanych w sprawach finansowych tego regimentu ${ }^{100}$. Nieco inna jest księga wydatków na utrzymanie lejbkompanii regimentu piechoty buławy polnej koronnej z lat 1757-1763, która zawiera zestawienia nakładów na umundurowanie i sprzę ${ }^{101}$. W archiwum Rzewuskich zachowały się także księgi lenungowe, a więc mające charakter list płac, na przykład księga lenungowa regimentu pieszego buławy polnej koronnej z lat 1753-1756 $6^{102}$. Ciekawą księgą jest również „Generalna kalkulacya Kassy Regimentowey pod bokiem JW wodza y Cheffa Dobrodzieja od Roku 1756 y Raty 80 Septembrowey w Podhorcach będącey" ${ }^{103}$, zawierająca rozliczenia związane ze ściąganiem należności z poszczególnych dóbr na płace w regimencie pieszym buławy polnej koronnej. Występują w niej między innymi rozliczenia z poborcami wysyłanymi z ramienia regimentu w celu pobierania należnych sum.

\footnotetext{
100 AP w Krakowie, APd II, sygn. 25.

101 Tamże, sygn. 42.

102 Tamże, sygn. 81.

103 Tamże, sygn. 64.
} 
Oprócz akt finansowych w formie ksiąg w archiwach hetmańskich znajdują się też akta luźne ${ }^{104}$. Na przykład likwidacja (zestawienie należności) chorągwi pancernej hetmana polnego Seweryna Rzewuskiego z raty wrześniowej $1783 \mathrm{r}$. przesłana departamentowi wojskowemu ${ }^{105}$, rolle lenungowe (listy wypłat żołdu) ${ }^{106}$ czy zestawienie płac na oficerów i żołnierzy regimentu pieszego buławy wielkiej koronnej Stanisława Mateusza Rzewuskiego ${ }^{107}$. Wiele tego rodzaju archiwaliów zachowało się również w archiwach Adama Mikołaja Sieniawskiego oraz Jana Klemensa Branickiego. Znajduje się w nich dokumentacja związana z regulacją płac przybocznych oddziałów hetmańskich. W archiwum Adama Sieniawskiego bardzo licznie występują rolle lenungowe i kwartalne jego oddziałów, między innymi regimentów pieszych buławy polnej i wielkiej koronnej ${ }^{108}$, oraz akta związane z rozliczeniami finansowymi chorągwi janczarskiej i kuruckiej, tworzących piechotę węgierską Sieniawskiego ${ }^{109}$. Należy także wspomnieć o asygnacjach wydawanych dla hetmańskich oddziałów, na podstawie których pobierały one swoje należności z dóbr ziemskich. Asygnacje były wystawiane przez różnych urzędników, wśród których generalnie najważniejszą rolę odgrywali podskarbi wielki koronny oraz hetman wielki koronny. W archiwum Sieniawskiego zachowały się liczne asygnacje, między innymi wystawione przez Hieronima Augustyna Lubomirskiego, hetmana wielkiego koronnego, a także przez podskarbiego wielkiego koronnego Jana Jerzego Przebendowskiego dla lejbkompanii regimentu arkebuzerskiego regimentu pieszego Sieniawskiego ${ }^{110}$.

Archiwum Jana Klemensa Branickiego tworzy wiele archiwaliów dotyczących tak zwanych exakcji, to jest pobierania należności, jakie poszczególne dobra miały wnosić na utrzymanie oddziałów wojskowych. Najczęściej akta tego rodzaju miały formę zestawień dochodów i wydatków z pobranych sum na poszczególne oddziały, tak zwane „Rachunki de perceptis et expensis z exakcji”. Między innymi środki na utrzymanie regimentu pieszego buławy wielkiej koronnej w okresie, kiedy jego szefem był Jan Klemens Branicki, pochodziły z dóbr powiatu gnieźnieńskiego, czego śladem jest tabelaryczne zestawienie sum, jakie

104 Obecnie często występują w formie zszytych rękopisów, ta uwaga dotyczy przede wszystkim archiwaliów znajdujących się w Bibliotece Czartoryskich w Krakowie.

105 AP w Krakowie, APhAP, sygn. VII, 9/5.

106 Tamże, sygn. V, 1/10, 12; VI, 1/41.

107 AP w Krakowie, Archiwum Sanguszków 1284-1945 [2000]: Archiwum Podhoreckie I (dalej: APd I), sygn. 89.

${ }^{108} \mathrm{BCz}$, sygn. $2626 \mathrm{IV}$, s. 125-195; sygn. 2652 IV, t. 2; sygn. 2653 IV, t. 3; sygn. $3126 \mathrm{IV}$.

109 Tamże, sygn. 2602 III; sygn. 2653 IV, t. 3; sygn. 3126 IV.

110 Tamże, sygn. 2883 IV. 
miały być pobierane na regiment z poszczególnych majątków tego powiatu ${ }^{111}$. Znajduje się tu także informacja na temat dotychczasowych wypłat na rzecz regimentu ściąganych przez tak zwanego exactora regimentowego, czyli oficera regimentu skierowanego do poboru należności. Akta podobnego rodzaju zachowały się również dla innych oddziałów hetmańskich Branickiego, szczególnie regimentu pieszego buławy polnej ${ }^{112}$ oraz chorągwi piechoty węgierskiej buławy wielkiej koronnej ${ }^{113}$.

Omawiając akta finansowe oddziałów hetmańskich, należy zwrócić uwagę na tak zwane likwidacje, będące zestawieniami płac przeznaczonych dla poszczególnych oddziałów, ustalonych przez Trybunał Skarbowy rezydujący w Radomiu. W archiwum Branickiego zachowały się między innymi likwidacje regimentu pieszego buławy polnej i wielkiej koronnej w postaci kilkudziesięciu poszytów, których treść stanowiły ekstrakty zaczerpnięte z oryginalnych ksiąg Archiwum Skarbu Koronnego ${ }^{114}$.

Częstym rodzajem dokumentacji finansowej, występującej w archiwach hetmańskich, są również listy płac żołnierzy ich oddziałów. O ile wcześniej miały one charakter indywidualnych pokwitowań na pojedynczych kartkach papieru, o tyle w późniejszym czasie przybrały one formę współczesnej listy płac. Jako przykłady można podać chociażby pokwitowania i listy płac z gaż i lenungów odebranych z kas regimentów pieszych buławy polnej i wielkiej za szefostwa Jana Klemensa Branickiego ${ }^{115}$ czy księgę zawierającą między innymi akta kapitulacji Adama Sieniawskiego z oficerami zaciągniętymi do jego oddziałów w latach $1703-1706^{116}$.

Bardzo ciekawy rodzaj dokumentacji aktowej związanej z oddziałami przybocznymi hetmanów stanowią księgi-dzienniki raportów z hauptwachu, to znaczy służby wartowniczej na zamku w Podhorcach, którą pełniły oddziały hetmańskie: lejbkompania regimentu pieszego buławy polnej, chorągiew węgierska i regiment dragonów ${ }^{117}$. Raporty $\mathrm{z}$ wart miały formę tabelaryczną i gromadziły informacje dotyczące: stanu liczebnego i imiennego oddziału wartowniczego, szczegółowego rozmieszczenia żołnierzy na posterunkach, aresztantów znajdujących się w pałacowym areszcie, osób przyjeżdżających i wyjeżdżających z Podhorzec, łącznie z rodziną hetmana, paroli, czyli haseł, oraz rozporządzeń wyda-

111 AGAD, ARo, Militaria, pudło 10, plik 4, CXLVI/110.

112 Tamże, pudło 11, plik 5.

113 Tamże, pudło 18, plik 1.

114 Tamże, pudło 10, plik 5; pudło 11, plik 6.

115 Tamże, pudło 10, pliki 6, 9; pudło 11, plik 9.

$116 \mathrm{BCz}$, sygn. 2675 III.

117 AP w Krakowie, APd II, sygn. 28, 67, 253, 268. 
nych przez hetmana i dowódcę straży dla służby wartowniczej. W archiwum Wacława Rzewuskiego zachowała się również nietypowa księga stanowiąca dziennik sądowy lejbkompanii regimentu pieszego buławy polnej koronnej z lat 1755-1762, zawierający opis inkwizycji (śledztw) i wydanych dekretów (wyroków) w sprawach karnych przeciw żołnierzom w niej służącym ${ }^{118}$.

Omawiając akta oddziałów hetmańskich, nie można pominąć ciekawego przypadku związanego także z archiwum Rzewuskich. Otóż w zasobie archiwum hetmańskiego znalazły się prywatne archiwalia dwóch oficerów służących w regimencie pieszym buławy polnej koronnej za hetmaństwa Wacława Rzewuskiego: Samuela Brodowskiego i Andrzeja Grotowskiego. Po Grotowskim, który umarł w 1757 r., pozostała w archiwum hetmańskim dokumentacja o charakterze prawno-majątkowym, oblaty umów i kontraktów działowych, korespondencja oraz sumariusz dokumentów ${ }^{119}$. Jak wynika z akt, po śmierci Grotowskiego toczył się spór pomiędzy jego spadkobiercami, Kasprem Grotowskim, podstolim i sędzią sochaczewskim, oraz Barbarą z Trzebińskich Rusocką, reprezentowaną przez Samuela Brodowskiego, a regimentem pieszym buławy polnej koronnej. Konflikt zakończył się ugodą, a jej wynikiem jest między innymi obecność archiwaliów Grotowskiego w archiwum Rzewuskich. Najprawdopodobniej na analogicznej zasadzie pozostały w archiwum podhoreckim akta po kapitanie Samuelu Brodowskim, na które składa się przede wszystkim korespondencja ${ }^{120}$.

\section{DokUmentacja OSOBista HETMANów}

Wśród zasobów archiwów hetmańskich należy wyodrębnić grupę archiwaliów, które odnoszą się bezpośrednio do samego urzędu hetmańskiego, a nie powstały w wyniku sprawowania władzy z nim związanej. Chodzi mianowicie o akty nominacji na hetmaństwo, listy przypowiednie na oddziały przyboczne hetmanów, archiwalia dotyczące zaopatrzenia urzędu hetmańskiego, w końcu korespondencję kierowaną do hetmanów w sprawach niewiążących się bezpośrednio z ich władzą nominalną, ale raczej z ich pozycją społeczną. Ta ostatnia grupa dokumentów jest najbardziej problematyczna, dlatego że trudno jednoznacznie określić charakter korespondencji. Niemniej jednak wydaje się, że jest to celowe ze względu na bardzo dużą liczbę listów kierowanych do hetmanów i ich różnorodność. W przypadku aktów nominacyjnych na urząd hetmański, które stawały się zaczątkiem archiwum hetmańskiego, można stwierdzić z całą

118 Tamże, sygn. 61.

119 AP w Krakowie, APd I, sygn. 134, 135, 136, 137; APhAP, sygn. I 1/1-57.

120 AP w Krakowie, APd I, sygn. 136, 137, 138, 139; APhAP, sygn. I 1/1-57. 
pewnością, że posiadał je każdy hetman koronny. Niestety, nie wszystkie akty nominacyjne zachowały się do dnia dzisiejszego. W większości podzieliły one los znacznej części archiwaliów z archiwów prywatnych i uległy rozproszeniu bądź też zniszczeniu. Stało się tak, mimo że stanowiły one w archiwach prywatnych, wraz z innymi aktami o charakterze przywilejów i nadań królewskich, szczególnie pieczołowicie przechowywaną grupę archiwaliów. $Z$ aktów nominacyjnych na urzędy hetmanów koronnych, które zachowały się w oryginale, można wymienić nadania hetmaństwa polnego dla Stanisława Żółkiewskiego ${ }^{121}$, Jerzego Sebastiana Lubomirskiego ${ }^{122}$, Stanisława Mateusza Rzewuskiego ${ }^{123}$, Jerzego Klemensa Branickiego ${ }^{124}$, Wacława Rzewuskiego ${ }^{125}$, Seweryna Rzewuskiego ${ }^{126}$. Natomiast z nominacji na hetmaństwo wielkie zachowały się akty Stanisława Żółkiewskiego ${ }^{127}$, Jana Sobieskiego ${ }^{128}$, Stanisława Mateusza Rzewuskiego ${ }^{129}$, Jana Klemensa Branickiego ${ }^{130}$, Wacława Rzewuskiego ${ }^{131}$.

Z aktami nominacyjnymi na urzędy hetmańskie są także związane listy przypowiednie na oddziały wojskowe, przysługujące hetmanom z racji sprawowanego urzędu. Zachowały się dwa takie listy wydane dla hetmana polnego Seweryna Rzewuskiego, jeden na chorągiew pancerną, a drugi na chorągiew husarską ${ }^{132}$. Oba były sygnowane w tym samym dniu co akt nominacyjny na hetmaństwo polne. To zapewne niejedyny przypadek takiej zbieżności w wystawianiu przez kancelarię królewską tego rodzaju dokumentów.

Dla osób piastujących hetmaństwo bardzo istotna była dokumentacja związana $\mathrm{z}$ ich finansowym uposażeniem. Kancelaria hetmańska sprawowała nad tymi aktami szczególną pieczę, gdyż stanowiły one podstawę rozliczania hetmanów z pobieranego przez nich wynagrodzenia. Skrupulatność tych rozliczeń świadczy o tym, że kwestie finansowe były obiektem wyjątkowego zaintereso-

121 AGAD, AR, Dział I, sygn. 774/18, Zbiór dokumentów pergaminowych AGAD, nr 7943.

122 Centralne Państwowe Historyczne Archiwum Ukrainy we Lwowie, Lubomirscy, f. 835, op. 1, spr. 1479.

123 AP w Krakowie, APd I, sygn. 83.

124 AGAD, ARo, Majątkowo-prywatne, sygn. 51, XCVIII 1/8.

125 AP w Krakowie, APhAP, sygn. XII/15/5(2).

126 Tamże, sygn. XII/7.

127 AGAD, Dział I, sygn. 926/138, Zbiór dokumentów pergaminowych AGAD, nr 8133.

128 Tamże, Dział X, pudło 15. Numer pudła nadany tymczasowo.

129 AP w Krakowie, APd I, sygn. 83.

130 AGAD, ARo, Majątkowo-prywatne, sygn. 51, XCVIII 1/8.

131 AP w Krakowie, APhAP, sygn. XII 18/2.

132 Tamże, sygn. XII 18/7-8. 
wania hetmanów. Oczywiście, te archiwalia stanowiły pierwotną część archiwów hetmańskich. Nie ulega bowiem wątpliwości, że akta o charakterze finansowym podlegały najczęstszej kontroli społeczeństwa szlacheckiego, tym bardziej jeśli dotyczyły wydatków ze skarbu Rzeczypospolitej. W początkowym okresie funkcjonowania hetmaństwa koronnego, kiedy to uposażenie hetmańskie nie było jasno określone, w archiwach mogły zachować się zasadniczo dwa rodzaje tej dokumentacji: pokwitowania z odebranych sum, wystawiane przez osobę przekazującą uposażenie hetmanowi (podobne oświadczenie składał również hetman bądź osoba przez niego upoważniona w momencie przejmowania wynagrodzenia), oraz asygnacje, czyli akty najczęściej wydawane przez króla lub podskarbiego, upoważniające hetmana do odbioru określonych należności w ustalonym miejscu i czasie. W późniejszym okresie, kiedy wysokość wynagrodzenia urzędów hetmańskich została jasno sprecyzowana, zmieniła się też nieco stosowna dokumentacja. Przede wszystkim było jej więcej.

Dokumentem finansowym, związanym $\mathrm{z}$ uposażeniem hetmanów, jest na przykład pokwitowanie Jana Klemensa Branickiego z pobranej hiberny z województwa krakowskiego z 1766 r. ${ }^{133}$, jak również asygnacje wystawione na rzecz hetmana polnego koronnego Stanisława Mateusza Rzewuskiego przez marszałka konfederacji sandomierskiej Stanisława Denhoffa z 1708 r. do Żydów lubelskich i Ordynacji Zamoyskiej oraz asygnacje wydane przez podskarbiego koronnego Jana Jerzego Przebendowskiego z 1710 r. do Żydów ostrogskich ${ }^{134}$. W archiwum Rzewuskich zachowała się ponadto korespondencja w sprawie wynagrodzenia hetmanów, między innymi pismo Komisji Rzeczypospolitej Skarbu Koronnego dotyczące wypłacenia dodatkowej sumy hetmanowi polnemu koronnemu Wacławowi Rzewuskiemu oraz dwa listy, podpisane ręką króla Stanisława Augusta, skierowane do Rzewuskiego, zawierające warunki wynagrodzenia dla hetmana wielkiego koronnego ${ }^{135}$. W tym miejscu trzeba również wspomnieć o dokumentacji nieodnoszącej się bezpośrednio do uposażenia hetmańskiego, ale do wynagrodzenia hetmanów za finansowanie przez nich wojska z prywatnej kasy. W zasadzie musiała ona występować w większości archiwów hetmańskich, gdyż nie ulega wątpliwości, że hetmani niejednokrotnie przeznaczali swe prywatne fundusze na cele publiczne. Oczywiście nie robili tego bezinteresownie, licząc zapewne nie tylko na ich zwrot, lecz także dodatkową nagrodę. Taki charakter ma „Likwidacja expens z gotowizny własnej J.O. Mści Pana Krakowskiego, hetmana w. koronnego na potrzeby publiczne uczynionych, które Rzplita hetmanom

133 AGAD, ARo, Majątkowo-prywatne, sygn. 51, XC.

134 AP w Krakowie, APhAP, sygn. IX 1/20, XI 1/5, 11; zob. też APd I, sygn. 88.

135 AP w Krakowie, APhAP, sygn. IX 3/46, XII 18/3, 5. 
bonifikować zwykła", odnosząca się do Adama Mikołaja Sieniawskiego ${ }^{136}$. Ten dokument dobrze świadczyłby o Sieniawskim, gdyby nie fakt, że nie był on hetmanem, którego można by stawiać za wzór cnót obywatelskich. Sieniawski mógł bowiem wystawiać asygnacje sam dla siebie i dla wiernych mu oddziałów, co skrzętnie wykorzystywał w celu pomnożenia swojego majątku. Ten proceder ułatwiał mu fakt braku realnych możliwości skontrolowania jego działalności finansowej przez okres co najmniej kilku lat wojny północnej ${ }^{137}$. Częstym zjawiskiem przy pobieraniu należności wojskowych był duży nieporządek, a przede wszystkim niewydolność systemu skarbowego. Narastały więc zaległości w spłacie podatków przeznaczonych na pensje wojskowych. Nie dziwi więc obecność w archiwach hetmańskich sumarycznych zestawień obejmujących wypłatę uposażenia z kilku lat ${ }^{138}$. Specyficzny charakter ma księga zestawiająca nakłady finansowe najprawdopodobniej hetmana Stanisława Jabłonowskiego z lat 1693-1696 $6^{139}$, zawierająca miesięczne wydatki hetmana wraz z krótkimi adnotacjami, na jaki cel były one przeznaczone. Znajdują się w niej między innymi bardzo ciekawe informacje o działalności dyplomatycznej i wywiadowczej prowadzonej z inicjatywy hetmana i opłacanej z jego prywatnej kasy.

$\mathrm{Z}$ uposażeniem hetmana należy również łączyć występowanie w hetmańskich archiwach przywilejów królewskich na dobra ziemskie. Nierzadko bowiem, szczególnie do połowy XVII w., hetmani otrzymywali w dowód wdzięczności za wywiązywanie się z nałożonych obowiązków majętności ziemskie. Częste kłopoty finansowe królów można było rozwiązać między innymi właśnie dzięki rozdawaniu królewszczyzn.

$\mathrm{Na}$ zakończenie warto wspomnieć także o kopiariuszach z kancelarii hetmańskich, które zawierały najczęściej różnego rodzaju odpisy akt związanych z działalnością hetmanów. Z reguły charakteryzują się one dużą różnorodnością tematyczną. Bardzo często obejmują korespondencję zarówno do, jak i od hetmanów. Wpisywano do nich też formularze różnych pism wychodzących z kancelarii hetmańskiej. Przykładem tego rodzaju dokumentacji może być kopiariusz z kancelarii hetmana Stanisława Jabłonowskiego, zawierający kopie pism wystawianych przez nią w latach 1692-1695: ordynanse, dekrety, kontumacje, uniwersały, suplementy, atestacje, libertacje sołtystw i inne ${ }^{140}$.

\footnotetext{
$136 \mathrm{BCz}$, sygn. $2624 \mathrm{IV}$, s. 1-45.

137 Tamże, sygn. 2645 IV, s. 349.

138 Tamże, sygn. 2640 IV, t. 2.

139 Tamże, sygn. 1949/IV.

140 Tamże, sygn. 2699/IV.
} 


\section{Archives of marshals of the Polish Crown. Definition, characteristics and typology of the documents}

Summary

Archives of great marshals (hetmani wielcy) and field marshals (hetmani polni) of the Polish Crown and of the Great Duchy of Lithuania functioned within an organisational framework very different to archives of other ministerial offices within the Polish-Lithuanian Commonwealth. Marshals' archives should be regarded as belonging to private archives and, to be more specific, as fragments of archives belonging to clans and families from which marshals descended. The documents written by marshals while they were in office were considered their private property and they were entered into archives as their personal, private files. This is how a paradox occured because documents written by a person holding one of the most important offices in the country, and who was often seen as dangerous for the nobility's and the ruler's own interests and for the country's security, could not be made known to the public and existed beyond any control. Various documents survived amongst the archives of the marshals of the Polish Crown, different in terms of form, sender and subject matter.

The first criterion that we can adopt while characterising the documentation found in marshals' archives is its form. Here, the first place definitely takes correspondence, followed by documents set out in tabular form, case files, books, and finally documents. Other criterion which can be applied is the sender and the addressee. According to this criterion, the documents can be divided into these incoming, addressed to marshal or people close to him (e.g. people working in his office), and these outgoing, written by marshal or people working with him. Another criterion used for typology of documentation found in marshals' archives is the subject matter, usually dependent of the function of marshal of the Polish Crown. And so the documents can be divided into the following categories: military, financial, judicial, diplomatic and private (these include documents related to the office held but referring directly to marshal, e.g. papers appointing to the office of marshal, documentation regarding remuneration, correspondence). Taking into consideration the fisical form in which the documents can be found at the moment, we can describe them as loose, glued or bound together. Certainly, all those forms could well be found in the past but it is important to remeber that the condition that the documents are in at present does not always correspond to their original form. They were usually produced as loose documents and were later bound into fascicles. 